Maurer School of Law: Indiana University

Digital Repository@ Maurer Law

Indiana Law Journal

Volume 94 | Issue 1

Article 4

Winter 2019

\title{
Beyond the Numbers: Substantive Gender Diversity in Boardrooms
}

Yaron G. Nili

University of Wisconsin-Madison, nili@wisc.edu

Follow this and additional works at: https://www.repository.law.indiana.edu/ilj

Part of the Civil Rights and Discrimination Commons, Law and Gender Commons, and the Securities Law Commons

\section{Recommended Citation}

Nili, Yaron G. (2019) "Beyond the Numbers: Substantive Gender Diversity in Boardrooms," Indiana Law Journal: Vol. 94 : Iss. 1 , Article 4.

Available at: https://www.repository.law.indiana.edu/ilj/vol94/iss1/4

This Article is brought to you for free and open access by the Law School Journals at Digital Repository @ Maurer Law. It has been accepted for inclusion in Indiana Law Journal by an authorized editor of Digital Repository @ Maurer Law. For more information, please contact rvaughan@indiana.edu.

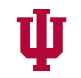

JEROME HALL LAW LIBRARY

INDIANA UNIVERSITY

Maurer School of Law
Bloomington 


\title{
BEYOND THE NUMBERS: SUBSTANTIVE GENDER DIVERSITY IN BOARDROOMS
}

\author{
YARON NILI*
}

The push for gender diversity on public companies' boards has been gaining traction. Advocacy groups, institutional investors, regulators, and companies themselves have all recognized the need for more diverse boards. However, gender parity is still absent from most public companies' boards, and a significant number of companies still have no women on their boards.

Current public and academic discourse has focused on the number of women serving on the board and their percentage compared to men as the litmus test for gender diversity. However, academic studies and the public push for more diversity have mostly failed to account for another important measure of board gender diversity - the actual role and clout that female directors have within the boardroom. This is what the Article terms as substantive gender diversity.

Substantive gender diversity matters. It is at the core of both the social cause and the business case for gender diversity on boards. This Article explores this substantive component of board gender diversity through empirical data relating to the roles that men and women play on corporate boards. The Article finds statistically significant differences between the roles of female and male directors. Building on these findings, the Article asserts that regulators, investors, and companies must focus not only on increasing the number of women on boards but also on ensuring that female directors enjoy similar parity once elected. The Article then proposes a shift towards a Substantive Gender Diversity Disclosure regime which would measure and report the substantive aspect of gender diversity in boardrooms.

INTRODUCTION. 146

I. GENDER DIVERSITY IN THE BOARDROOM-WHAT'S AT STAKE 153

A. THE BOARD OF DIRECTORS' IMPORTANT ROLE IN THE GOVERNANCE OF THE CORPORATION 153

B. GENDER DIVERSTY ON CORPORATE BOARDS . 155

C. The Two-Headed CASE For Gender Diversity ON CORPORATE BOARDS

* Assistant Professor of Law, University of Wisconsin Law School. I would like to thank Aaron Dhir, Lisa Fairfax, Jesse Fried, Cathy Hwang, Kobi Kastiel, Gwyn Leachman, Amanda Packel, Darren Rosenblum, Miriam Seifter, David Schwartz, David Webber, Rob Yablon and the participants at the University of Wisconsin Law School Faculty Workshop, the University of Minnesota Law School Faculty Works in Progress Workshop, the 2017 annual meeting of the American Law and Economics Association, the 2017 National Business Law Scholars Conference, and the 2017 annual meeting of the Midwestern Law and Economics Association for their helpful comments. Justin Top, Chris Krewson, Will Conley, Rachel Gallagher, and Jake Levine provided valuable research assistance. Support for this research was provided by the Office of the Vice Chancellor for Research and Graduate Education at the University of Wisconsin-Madison with funding from the Wisconsin Alumni Research Foundation. 
1. The Social CaUSe CASE for Gender Diversity ...................... 159

2. THE INSTRUMENTAL CASE FOR GENDER DIVERSITY.................... 160

A. BOTTOM LINE PERFORMANCE …....................................... 160

B. BOARD DYNAMICS AND GOVERNANCE .............................. 162

D. THE MISSING DIMENSION: SUBSTANTIVE GENDER DIVERSITY ............. 164

II. GENDER DIVERSITY-EMPIRICAL FINDINGS ............................................... 165

A. QuANTITATIVE GENDER DIVERSITY.................................................... 166

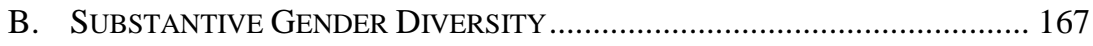

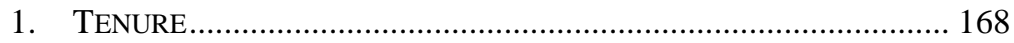

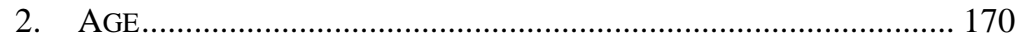

3. CHAIR POSITIONS ………………………………………....... 170

4. LEAD INDEPENDENT DIRECTOR ROLE......................................... 171

5. SERVICE ON OTHER BOARDS..................................................... 172

6. SERVICE ON BOARD COMMITTEES …………………................... 173

A. AVERAGE NuMBER OF COMMITTEES .................................. 174

B. Percent of MEN AND Women on At Least One BOARD COMMITTEE ....................................................... 174

C. LIKELIHOOd OF SITTING ON A GIVEN NUMBER OF

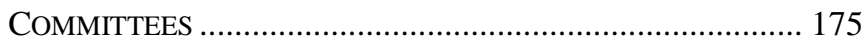

D. LiKeliHOOd OF SitTING ON A Given COMMITTEE ............. 177

C. KEY LESSONS FROM THE FINDINGS ………………............................ 180

III. THE REgULATORY FRAMEWORK AND ITS CURRENT FlaWS............................ 182

A. The EVolution of Diversity DisClosure REQUIREMENTS .............. 183

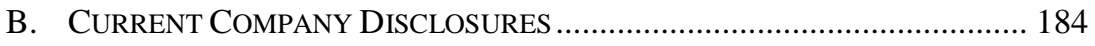

C. THE FLAWS WITH CURRENT DisclosuRES........................................... 187

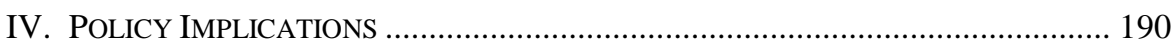

A. A Focus on SubSTANTIVE DivERSITY ……………......................... 191

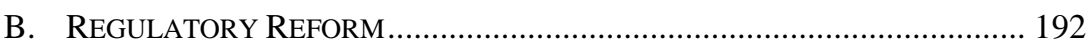

1. THE DEFINITION OF DIVERSITY …………………….................... 195

2. ADDING A SUBSTANTIVE GENDER DIVERSITY DISCLOSURE ....... 196

C. IMPLEMENTATION THROUGH OTHER MEANS ......................................... 197

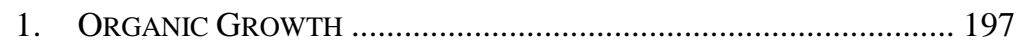

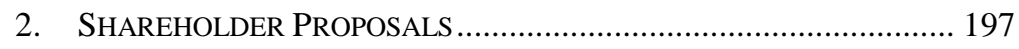

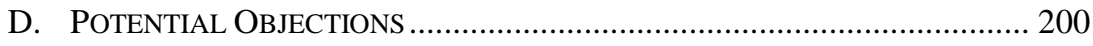

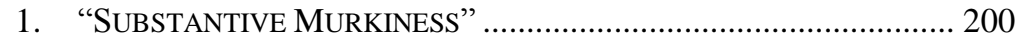

2. OVERINCLUSIVENESS ............................................................... 200

3. Questionable Diversity Practices Will Persist................. 201

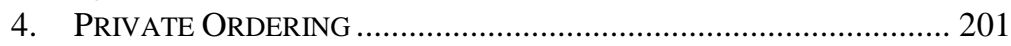

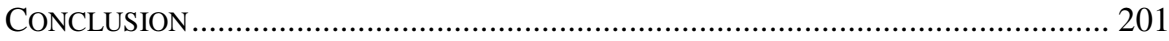

\section{INTRODUCTION}

She appeared in the middle of the night on the eve of International Women's Day 2017. ${ }^{1}$ Staring defiantly at one of the most iconic symbols of corporate America in

1. 'Fearless Girl' Statue Stares Down Wall Street's Bull, Detroit News (Mar. 8, 2017, 
Manhattan, the Fearless Girl statue by Kristen Visbal is a symbol of the increased attention by investors and the public to the lack of gender diversity within corporate boardrooms in the United States. ${ }^{2}$ Though the statue's location was temporary, ${ }^{3}$ State Street Global Advisors, who commissioned the statue, took a more long-lasting step towards promoting board diversity by voting against 400 corporate boards with no female directors. ${ }^{4}$ While the $\$ 2.47$ trillion asset manager will not require a female director quota, companies must now show concrete attempts to remedy their nominating procedures to encourage female nominees in order to avoid a negative vote. ${ }^{5}$ This resolute act mirrors what has steadily become a new focus for boardrooms and investors: gender diversity.

Calls for increased gender diversity in boardrooms are not new, ${ }^{6}$ but the effort to achieve better gender parity has come to the forefront of corporate governance discourse in recent years. On the heels of mandatory quotas for female directors in many European countries, ${ }^{7}$ and with increasing evidence suggesting that boardroom diversity increases company performance, ${ }^{8}$ the push for diversity has gained traction

11:07 AM), https://www.detroitnews.com/story/news/nation/2017/03/08/fearless-girl-wall -street/98898896 [https://perma.cc/MWM8-7AAC].

2. Peter A. Szekely, On Women's Day Eve, Statute of Girl Stares Down Wall Street Bull, REUTERS (Mar. 7, 2017, 2:48 PM), http://www.reuters.com/article/us-womens-day-usa -idUSKBN16E2M8 [https://perma.cc/6DUE-V9S4].

3. Beth Healy, State Street Global Advisors Presses Companies It Invests in to Add Women to Boards, Bos. GLOBE (Mar. 7, 2017), https://www.bostonglobe.com /business/2017/03/07/state-street-global-advisors-presses-companies-invests-add-womenboards/cE1LWXt6tK7DfveYnIFmpJ/story.html [https://perma.cc/6DUE-V9S4]; Liz Moyer, 'Fearless Girl' Will Be Moving to NYSE After Spending a Year Staring Down 'Charging Bull', CNBC (Apr. 19, 2018, 11:40 AM), https://www.cnbc.com/2018/04/19/fearless-girl-moving -to-nyse-after-spending-a-year-staring-down-charging-bull.html [https://perma.cc/AW9C -AR6R].

4. Justin Baer, State Street Votes Against 400 Companies Citing Gender Diversity, WALL ST. J. (July 25, 2017, 8:38 PM), https://www.wsj.com/amp/articles/state-street-votes -against-400-companies-citing-gender-diversity-1501029490 [https://perma.cc/E2F9-AP6P].

5. Joann S. Lublin \& Sarah Krouse, State Street to Start Voting Against Companies that Don't Have Women Directors, Wall ST. J. (Mar. 7, 2017, 12:01 AM), https://www.wsj .com/articles/state-street-says-it-will-start-voting-against-companies-that-dont-have-women -directors-1488862863 [https://perma.cc/G2UV-M6W8].

6. See, e.g., Rosabeth Moss Kanter, Men and Women of the Corporation (2d ed. 1993); Rosabeth Moss Kanter, Some Effects of Proportions on Group Life: Skewed Sex Ratios and Responses to Token Women, 82 AM. J. Soc. 965, 966 (1977) (arguing in 1977 for critical mass theory and the need for boards to have at least thirty-five percent of directors be female to introduce new perspectives and increase corporate performance).

7. Douglas M. Branson, Initiatives to Place Women on Corporate Boards of DirectorsA Global Snapshot, 37 J. Corp. L. 793, 803 (2012); European Commission, Gender Balance on Corporate Boards: Europe is Cracking the Glass Ceiling (Mar. 2014), https://www.genderportal.eu/sites/default/files/resource_pool/FS-WOB-FINAL-EN -WEB.pdf [https://perma.cc/7DPD-YXQ9].

8. Lois Joy, Nancy M. Carter, Harvey M. Wagner \& SRIRAm Narayanan, Catalyst, The Bottom Line: Corporate Performance and Women's Representation ON BOARDS (2007), https://www.catalyst.org/system/files/The_Bottom_Line_Corporate _Performance_and_Womens_Representation_on_Boards.pdf [https://perma.cc/45NP-WQDP]. 
within the investor community. ${ }^{9}$ In addition to State Street, Vanguard and BlackRock have also taken public steps to promote and advocate for greater board diversity. ${ }^{10}$ Even more recently, the New York City Comptroller and the New York City Pension Funds launched their own initiative focusing on board diversity disclosure, ${ }^{11}$ and Institutional Shareholder Services Inc. (ISS) and Glass Lewis, the two largest and most influential proxy advisory firms, have announced a new focus on gender diversity. ${ }^{12}$

Congress is also becoming more involved in the efforts to improve board diversity. In May 2017, Representatives Carolyn B. Maloney and Donald S. Beyer sent a letter to newly confirmed Securities and Exchange Commission (SEC) Chair Jay Clayton urging him to take action on women's underrepresentation on corporate boards, with the accompanying press release stating that "[t]he SEC has the opportunity and ability to enforce the transparency that is critical to securing gender balanced corporate leadership. Boardrooms with gender parity lead stronger, healthier companies, return more to their shareholders, and help our economy grow." 13

According to a recent study, companies with the highest percentage of women on their boards had a rate of return nearly fifty-three percent higher than companies with the lowest percentage of female board members. ${ }^{14}$ Indeed, while the social duty to promote equality remains paramount to diversity initiatives, the emerging empirical

9. Healy, supra note 3 .

10. See, e.g., Emily Chasan, BlackRock Puts Its Votes Behind Proposals to Get Women on Boards, BLOOMBERG (July 13, 2017, 8:02 PM), https://www.bloomberg.com/news/articles /2017-07-14/blackrock-puts-its-votes-behind-proposals-to-get-women-on-boards [https:// perma.cc/64V2-T7P5]; Ryan Vlastelica, Vanguard Calls for More Diverse Corporate Boards, Better Climate-Change Disclosures, MARKETWATCH (Sept. 1, 2017, 7:37 AM), https://www .marketwatch.com/story/vanguard-calls-for-more-diverse-corporate-boards-better-climate -change-disclosures-2017-08-31 [https://perma.cc/22QU-875L].

11. Abe M. Friedman, Erica K. Lukoski, Bob McCormick \& Eric Sumberg, NYC Pension Funds Boardroom Accountability Project Version 2.0, HARV. L. SCH. F. CORP. GOVERnANCE \& FIN. REG. (Sept. 19, 2017), https://corpgov.law.harvard.edu/2017/09/19/nyc-pension-funds -boardroom-accountability-project-version-2-0 [https://perma.cc/6X9K-KAPQ].

12. Press Release, ISS, ISS Announces 2018 Benchmark Policy Updates (Nov. 16, 2017), https://www.issgovernance.com/iss-announces-2018-benchmark-policy-updates [https:// perma.cc/AQ5G-XSWN] (adopting a new policy on board gender diversity in Canada); Dimitri Zagoroff, Policy Guidelines Updated: United States, Canada, Shareholder Initiatives GLASS LEwIS (Nov. 22, 2017), http://www.glasslewis.com/policy-guidelines-updated-united -states-canada-shareholder-initiatives [https://perma.cc/3M8D-LZS4] (stating that the company's 2018 guidelines will feature an increased discussion of board gender diversity in its reports, including a phased policy that will see nomination committee chairs targeted with against/withhold recommendations if boards do not include a female director or provide a cogent explanation for their absence, by 2019).

13. Letter from Carolyn B. Maloney \& Donald S. Beyer, Jr., Members of Congress, to Jay Clayton, Chair, SEC (May 30, 2017), https://maloney.house.gov/sites/maloney .house.gov/files/Maloney\%20Beyer\%20Ltr\%20Clayton\%205.30.2017.pdf [https://perma.cc /6MSU-DLYS]; Press Release, Carolyn B. Maloney, Reps. Maloney and Beyer Press New SEC Chairman to Act on Boardroom Diversity (May 30, 2017), https://maloney.house .gov/media-center/press-releases/reps-maloney-and-beyer-press-new-sec-chairman-to-act -on-boardroom [https://perma.cc/QG5A-XF4U].

14. JOY ET AL., supra note 8. 
evidence suggesting better rates of return with more diverse boardrooms has transformed the public discourse in a profound way. Diversity is no longer just a desirable social cause, advocated for by advocacy groups and third-sector actors; ${ }^{15}$ it is now also a matter of better corporate governance and thus can enjoy, and harness, the support of the investor community - in particular large institutional investors. ${ }^{16}$

Yet, even with the recent pressure from legislatures and investors, as of 2017 , women comprised merely $16.2 \%$ of corporate boards. ${ }^{17}$ Many companies still have no female directors on their board, ${ }^{18}$ with some companies failing to have had any female directors over the past decade. ${ }^{19}$

The lack of gender diversity in boardrooms is further exacerbated by the lack of sufficient turnover at the board level. ${ }^{20}$ With very few board seats opening to new directors each year, ${ }^{21}$ improving diversity becomes increasingly difficult. However, boards and investors are intent on addressing this concern. Existing trends towards board refreshment, as part of the growing emphasis on director independence, will certainly present boards with more opportunities to appoint new female directors in an effort to improve gender diversity in the boardroom. ${ }^{22}$ Indeed, women and minorities accounted for half of the 397 newest independent directors at S\&P 500 companies in $2017 .^{23}$

15. See Lublin \& Krouse, supra note 5 .

16. Anthony Goodman \& Rusty O'Kelley, Institutional Investors Lead Push for GenderDiverse Boards, HARV. L. Sch. F. CORP. GovernANCE \& Fin. Reg. (Apr. 26, 2017), https:// corpgov.law.harvard.edu/2017/04/26/institutional-investors-lead-push-for-gender-diverse -boards [https://perma.cc/43TH-CFFY]. A recent ISS survey found that more than two-thirds (sixty-nine percent) of investor respondents consider it problematic if there are zero female directors on a public company board. ISS, supra note 12 .

17. DAN MARCEC, Equilar, Equilar GENDER Diversity IndEX: Q3 2017 (Nov. 8, 2017), https://www.equilar.com/reports/52-gender-diversity-index-q3-2017 [https://perma.cc/8FZK -WQ3T] (providing data for the Russell 3000 index); Joann S. Lublin, Dozens of Boards Excluded Women for Years, WALL ST. J. (Dec. 27, 2016, 9:03 AM), https://www .wsj.com/articles/dozens-of-boards-excluded-women-for-years-1482847381 [https://perma .cc/LF62-LVPW] (providing similar statistics for the Fortune 1000 companies).

18. Anders Keitz, Five $S \& P 500$ Boards Have No Women as Gender Balance Growth Stalls, YAHOO! FinANCE (June 26, 2017), https://finance.yahoo.com/news/five-p-500-boardsno-161700143.html [https://perma.cc/2FMK-QMCL]; Lublin, supra note 17; Quick Take: Women on Corporate Boards Globally, CATALYST (Mar. 16, 2017), https://www .catalyst.org/knowledge/women-corporate-boards-globally [https://perma.cc/3EW9-C5EL].

19. Lublin, supra note 17.

20. See Aaron A. Dhir, Challenging Boardroom Homogeneity: Corporate Law, GOVERNANCE, AND DiVERSITY 44 (2015) (describing the refreshment problem); N.Y. STOCK EXCH., NYSE: CORPORATE GOVERnANCE GuIDE, at iv (Steven A. Rosenblum et al. eds., 2014).

21. Spencer Stuart, 2017 Spencer Stuart BoArd Index Survey (2017), https://www.spencerstuart.com/research-and-insight/ssbi-2017-perspective [https://perma.cc /X6EX-3BWW] (noting that board turnover remains low and hinders meaningful progress in the percentage of women and minorities in boardrooms).

22. $I d$.

23. Id. According to a recent survey released by Spencer Stuart of 397 independent director slots open in the 2017 proxy season, $36 \%$ went to women. See SPENCER STUART supra note 21; see also Jeff Green, Women and Minorities Are the Majority of New Board Seats for the First Time, BLOOMBERG (Dec. 6, 2017, 11:15 AM), https://www.bloomberg.com/news 
Still, these opportunities must be utilized appropriately and advance meaningful gender diversity and equality in the boardroom. The now-infamous incident at Uber, when David Bonderman, the cofounder of the acclaimed private equity firm TPG, said that more women on the board means "more talking," ${ }^{4}$ points to a larger concern: do women get a fair and equal chance to contribute? Indeed, when it comes to gender diversity in corporate boardrooms, numbers matter, but so do the specific roles that women take on while on the board.

As this Article argues and empirically demonstrates, there is a fundamental difference between solely meeting numerical diversity "targets" and achieving true diversity in the boardroom. Therefore, investors and advocates of gender diversity must not only account for the ratio of gender-diverse directors in the boardroom. They must also account for the roles and functions that these directors serve once elected to the board-what in other contexts is often termed as substantive equality. ${ }^{25}$

Contemporary academic discourse on the topic of gender diversity on boards can be divided into three main strands. First, there are studies that survey the current landscape of board gender diversity. ${ }^{26}$ These studies examine the number of women currently filling board directorships as well as historical trends related to gender diversity. ${ }^{27} \mathrm{~A}$ second strand examines the impact of gender diversity on the financial performance of a company, attempting to determine whether boards that are more diverse improve performance or other observable characteristics of companies. ${ }^{28}$ Finally, a third strand centers on the social understanding of board diversity, asking how gender effects board dynamics and operation. ${ }^{29}$ Taken together, many of these

/articles/2017-12-06/women-minorities-capture-most-new-board-seats-for-first-time [https:// perma.cc/PM9A-Y84Y].

24. Mike Isaac \& Susan Chira, David Bonderman Resigns from Uber Board After Sexist Remark, N.Y. TimES (June 13, 2017), https://www.nytimes.com/2017/06/13/technology/uber -sexual-harassment-huffington-bonderman.html [https://perma.cc/7V6Z-DCNH].

25. See, e.g., Nancy Ehrenreich, Foreword: Conceptualizing Substantive Justice, 13 J. GENDER RACE \& JUST. 533 (2010); Michel Rosenfeld, Substantive Equality and Equal Opportunity: A Jurisprudential Appraisal, 74 CALIF. L. REV. 1687 (1986).

26. See, e.g., Deloitte, Women in the Boardroom: A Global Perspective (4th ed. 2015), https://www2.deloitte.com/content/dam/Deloitte/global/Documents/Risk/gx-ccg -women-in-the-boardroom-a-global-perspective4.pdf [https://perma.cc/V4Q7-HTUT]; BoRIS Groysberg, Yo-Jud Cheng \& Deborah Bell, Spencer Stuart \& WOMENCORPORATEDirectors Foundation, 2016 Global BoARd of Directors Survey (2016), https://c.ymcdn.com/sites/www.womencorporatedirectors.com/resource/resmgr /Knowledge_Bank/WCDBoardSurvey2016_FINAL.pdf [https://perma.cc/47RN-Z83U]; JoY ET AL., supra note 8.

27. DeloitTE, supra note 26; GROYSBERG ET AL., supra note 26; JOY ET AL., supra note 8.

28. See, e.g., Jasmin Joecks, Kerstin Pull \& Karin Vetter, Gender Diversity in the Boardroom and Firm Performance: What Exactly Constitutes a "Critical Mass?", 118 J. Bus. EтHICS 61 (2012); Joana Marinova, Janneke Plantenga \& Chantal Remery, Gender Diversity \& Firm Performance: Evidence from Dutch and Danish Boardrooms, 27 INT'L J. Hum. ResourCe MGMT. 1777 (2016).

29. See, e.g., Nada K. Kakabadse, Catarina Figueira, Katerina Nicolopoulou, Jessica Hong Yang, Andrew P. Kakabadse \& Mustafa F. Özbilgin, Gender Diversity and Board Performance: Women's Experiences and Perspectives, 54 Hum. Resource Mgmt. 265 (2015). 
studies ultimately conclude that either economic or moral forces (or both) support the push for increasing board diversity. ${ }^{30}$

Until this point, however, current academic discourse has had a dearth of empirical data dissecting the specific roles of women once they are elected to serve on a board and contrasting them with their peer male directors. ${ }^{31}$ For instance, information is still lacking concerning important questions such as: what board committees do women tend to sit on $;^{32}$ do they hold similar leadership roles; what is their tenure compared to their male counterparts; and what industries have higher percentages of female participation? Such details help reveal whether the metaphorical glass ceiling is truly broken for an individual woman once she enters a boardroom or whether female directors are still subject to disparities even while serving as directors.

The answer to this question is central to gender diversity discourse. As this Article demonstrates ${ }^{33}$ substantive gender diversity on boards matters. It matters if you believe in gender diversity on boards as part of a social cause. It also matters if you believe that gender-diverse boards lead to better company performance.

This Article is the first to examine this question in detail and to provide data on both an absolute as well as relative level of female participation in the boardroom.

30. See Deloitte, supra note 26; Groysberg ET AL., supra note 26; Joy ET AL., supra note 8; Joecks et al., supra note 28; Marinova et al., supra note 28; see also Vathunyoo Sila, Angelica Gonzalez \& Jens Hagendorf, Women on Board: Does Boardroom Gender Diversity Really Affect Firm Risk?, 36 J. CORP. FIN. 26 (2016) (finding a negative relationship between gender diversity and equity risk); Silva Del Prete \& Maria Lucia Stefani, Women as 'Gold Dust': Gender Diversity in Top Boards and the Performance of Italian Banks, (Banca D'Italia, Working Paper No. 1014, 2015), https://www.bancaditalia.it/pubblicazioni/temi-discussione /2015/2015-1014/en_tema_1014.pdf?language_id=1 [https://perma.cc/KS97-WGUY] (finding increased women on Italian bank boards has a positive effect on both the quality of credit and bank profitability); Marcus Noland, Tyler Moran \& Barbara Kotschwar, Is Gender Diversity Profitable? Evidence from a Global Survey, (Peterson Inst. for Int'1 Econ., Working Paper No. 16-3, 2016), https://piie.com/system/files/documents/wp16-3.pdf [https://perma .cc/E2GA-5AVC] (finding data from more than ninety-one countries suggests the presence of women in the boardroom or upper management improves a company's financial performance).

31. There are three earlier studies that have charted limited (and now dated) data regarding committee roles of women, but without contrasting the data to men or controlling for the women ratio on the board. See Dan R. Dalton \& Catherine M. Dalton, Women and Corporate Boards of Directors: The Promise of Increased, and Substantive, Participation in the Post Sarbanes-Oxley Era, 53 Bus. Horizons 257 (2010); Idalene F. Kesner, Directors' Characteristics and Committee Membership: An Investigation of Type, Occupation, Tenure, and Gender, 31 Acad. Mgmt. J. 66 (1988); Craig A. Peterson \& James Philpot, Women's Roles on U.S. Fortune 500 Boards: Director Expertise and Committee Memberships, $72 \mathrm{~J}$. Bus. EтнICS 177 (2007). A more recent study has focused on women's committee work in relation to their compensation. See Laura Casares Field, Matthew E. Souther \& Adam S. Yore, Does Diversity Pay in the Boardroom? (2d Annual Fin. Insts., Regulation \& Corp. Governance Conference) (Mar. 14, 2018) (unpublished manuscript), https://papers.ssrn.com/sol3 /papers.cfm?abstract_id=2810543 [https://perma.cc/74P5-J3QK].

32. Board committee service correlates with the ability of directors to exert influence on corporate policy. See infra notes 54-58 and accompanying text.

33. See infra Section I.D (discussing the importance of substantive gender diversity to both strands of justifications for gender diversity on boards). 
The Article, for the years 2007 to 2015, examines the ratio of women on boards within the S\&P 1500 companies, their board leadership roles, whether these women would be classified as "busy" or "overboarded directors," 34 the length of their tenure, and their likelihood of key board committee participation. Additionally, these numbers are compared with similar metrics for their male counterparts.

The empirical findings reveal significant differences between male and female directors, extending from their tenure to the roles they hold while on the board. Women have shorter tenures, are less likely to hold leadership roles, and are stretched more thinly than their male counterparts. ${ }^{35}$ These previously underexplored differences highlight that in addition to the highly addressed quantitative gender disparity on U.S. boards lies an equally concerning substantive gender disparity ${ }^{36}$ that has yet to be addressed. Accordingly, current calls for board diversity and the current disclosure regime must internalize the lessons these new empirical data present. Gender diversity discourse, therefore, must look beyond the numbers of female directors on the board and account for the roles that these directors take once appointed.

Underscoring the fact that current disclosure practices of companies do little to provide investors with information regarding the board's gender diversity, the Article then brings together these two strands-the importance of substantive gender diversity and the deficiencies in the current disclosure regime - by calling for a shift towards an enhanced disclosure regime. Specifically, the Article advocates for the SEC to require companies to provide investors with both substantive and quantitative measures of gender diversity on the boardroom through the adoption of a Substantive Gender Diversity Disclosure (SGDD) form.

Part I of this Article provides an overview of the importance of gender diversity in the boardroom, the different justifications for improving gender diversity, and the importance of substantive gender diversity to these justifications. Part II provides the results of the empirical analysis and an interpretation of the findings. Part III

34. Busy directors are directors who participate on multiple boards and therefore may be "too busy" engaging in their various director activities. See, e.g., ISS, 2016 BENCHMARK POLICY RECOMMENDATIONS 6 (Nov. 20, 2015), https://www.issgovernance.com/file /policy/2016-americas-policy-updates.pdf [https://perma.cc/4ZLE-4M9R] (summarizing academic research defining "busy" as a director who serves on three or more boards). Overboarded directors are similarly defined as directors who sit on too many boards. See ISS, United States Proxy Voting Guidelines 12 (Jan. 4, 2018), https://www.issgovernance .com/file/policy/active/americas/US-Voting-Guidelines.pdf [https://perma.cc/E3Z4-QJ29]. ISS indicated it would vote against a director sitting on more than five public company boards or if a CEO, on more than one additional board. Id.

35. These results confirm earlier observations regarding increased committee work for women. See, e.g., Pornsit Jiraporn, Manohar Singh \& Chun I. Lee, Ineffective Corporate Governance: Director Busyness and Board Committee Memberships, 33 J. BANKING \& Fin. 819 (2009).

36. This Article uses the term "substantive gender diversity" in a manner that varies from the usage of "substantive equality" in the literature in other contexts, in particular the antidiscrimination literature. Specifically, in this Article the term "substantive gender diversity" is focused on ensuring gender inclusion beyond the numerical ratio of women. Broad discussion of substantive equality as defined in the antidiscrimination literature is beyond the Article's scope. See supra note 25 and accompanying text. 
discusses the current regulatory framework and its flaws, and Part IV discusses the policy implications, advancing a call for an improved gender diversity disclosure regime.

\section{GENDER DIVERSITY IN THE BOARDROOM-WHAT'S AT STAKE}

\section{A. The Board of Directors' Important Role in the Governance of the Corporation}

Gender diversity in the boardroom is of particular interest due to the important role of boards in modern U.S. corporate governance.

As the core organ of the modern corporation, the board is tasked with several important roles in the governance of the corporation. ${ }^{37}$ First, while most of the operational decision-making can be, and is, delegated to management, the board is still required to be an active participant in some of the more important managerial business decisions, such as mergers, stock issuance, and change of company governance documents. ${ }^{38}$ Second, the board is a resource for management to utilize. The board provides insight and advice, as well as networking benefits, and facilitates the firm's access to various resources. ${ }^{39}$

Third, the board is charged with a monitoring role. ${ }^{40}$ The dispersed ownership structure of U.S. publicly held corporations ${ }^{41}$ presents a severe agency cost between management and shareholders. ${ }^{42}$ Shareholders' lack of incentive to supervise management due to their dispersed ownership, coupled with free riding concerns, effectively leads to a managerial controlled corporate structure. One of the first institutions asked to mitigate this agency issue was the board of directors. ${ }^{43}$ The board is expected to represent shareholders' interest vis-à-vis management, ${ }^{44}$ curtailing management's ability to extract private benefits or act in a suboptimal way with respect to shareholder interests. ${ }^{45}$ While the recent rise in shareholder activism

37. Melvin Aron Eisenberg, Legal Models of Management Structure in the Modern Corporation: Officers, Directors, and Accountants, 63 CALIF. L. REv. 375, 376 (1975).

38. See Stephen M. Bainbridge, Corporate Governance After the Financial Crisis 45-46 (2012).

39. See id. at $45-47$.

40. See Stephen M. Bainbridge, The New Corporate Governance in theory and PRACTICE 155-67 (2008) (detailing the role of the board monitoring management); JONATHAN R. Macey, Corporate Governance: Promises KePt, Promises Broken 50 (2008) (listing major corporate governance mechanisms for U.S. public companies); Jill E. Fisch, Taking Boards Seriously, 19 CARDOZO L. REV. 265, 268-72 (1997).

41. Adolf A. Berle, Jr. \& Gardiner C. Means, The Modern Corporation and Private Property 7 (rev. ed. 1991).

42. Agency cost can be defined as the "costs of structuring, monitoring, and bonding a set of contracts among agents with conflicting interests." Eugene F. Fama \& Michael C. Jensen, Separation of Ownership and Control, 26 J. L. \& ECON. 301, 304 (1983).

43. See Jeffrey N. Gordon, The Rise of Independent Directors in the United States, 19502005: Of Shareholder Value and Stock Market Prices, 59 StAN. L. Rev. 1465, 1468-69 (2007).

44. See BAINBRIDGE, supra note 40, 155-57 (detailing the role of the board and its importance in the governance of the firm).

45. See Michelle M. Harner, Corporate Control and the Need for Meaningful Board 
by hedge funds ${ }^{46}$ and the rise in institutional investors' engagement with companies ${ }^{47}$ have given shareholders a better ability to counteract these monitoring concerns, the board has taken an even greater role in the engagement with shareholders. ${ }^{48}$ The board, therefore, has become a conduit, allowing investors to formally and informally engage with the company. ${ }^{49}$

Importantly, while boards meet regularly, often eight to twelve times a year, ${ }^{50}$ many important board decisions are delegated to specific board committees, which are tasked with a particular mandate. Board committees meet separately from the full board, are composed of subsets of board members, and tend to have specific, narrowly defined functions. ${ }^{51}$ While boards may have various committees, there are several key committees that all publicly traded companies must maintain ${ }^{52}$ and that are often cited as having the greatest influence on corporate governance. ${ }^{53}$ These key

Accountability, 94 MinN. L. REV. 541, 583-84 (2010) (focusing on the boards' broader duties in the context of a controlling shareholder); see also Arthur B. Laby, The Fiduciary Obligation as the Adoption of Ends, 56 BuFF. L. REV. 99, 129-35 (2008) (describing directors' fiduciary duty to adopt shareholders' ends).

46. See, e.g., Matthew R. Denes, Jonathan M. Karpoff \& Victoria B. McWilliams, Thirty Years of Shareholder Activism: A Survey of Empirical Research, 44 J. CoRP. FIN. 405 (2017) (summarizing and synthesizing the findings from seventy-three studies that examine the effects of shareholder activism); Stuart L. Gillan \& Laura T. Starks, The Evolution of Shareholder Activism in the United States, 19 J. APPLIED CORP. FIN 55 (2007); Jim Rossman, Chris Couvelier \& Kashyap Shah, Review of Shareholder Activism: 1 H 2018, HARV. L. SCH. F. CORP. GOvERNANCE \& FIN. REG. (July 30, 2018), https://corpgov.law.harvard.edu/2018 /07/30/review-of-shareholder-activism-1h-2018 [https://perma.cc/W8WU-N4T7].

47. Paula Loop, Catherine Bromilow \& Leah Malone, The Changing Face of Shareholder Activism, Harv. L. Sch. F. Corp. Governance \& Fin. Reg. (Feb. 1, 2018), https://corpgov .law.harvard.edu/2018/02/01/the-changing-face-of-shareholder-activism [https://perma.cc /L6WG-MRJY].

48. See Krystal Gaboury Berrini \& Rob Zivnuska, Board Lessons: Succeeding with Investors in a Crisis, Harv. L. SCH. F. CorP. Governance \& Fin. ReG. (June 5, 2018), https://corpgov.law.harvard.edu/2018/06/05/board-lessons-succeeding-with-investors-in-a -crisis [https://perma.cc/8Y3P-GMSW].

49. See Martin Lipton, Spotlight on Boards 2018, Harv. L. Sch. F. CorP. Governance \& FIN. REG. (May 31, 2018), https://corpgov.law.harvard.edu/2018/05/31/spotlight-on -boards-2018 [https://perma.cc/5EN2-SZ4L].

50. See SPEnCER StuART, supra note 21 (stating that in 2017 boards met an average of 8.2 times).

51. See Eileen Morgan Johnson, The Basics of Board Committee Structure, ASAE (Dec. 21, 2015), https://www.asaecenter.org/resources/articles/an_plus/2015/december/the-basics -of-board-committee-structure [https://perma.cc/RSR6-6TAQ].

52. See Yaron Nili, The "New Insiders": Rethinking Independent Directors' Tenure, 68 HASTINGS L.J. 97, 109-10 (2016); see also SPENCER STUART, supra note 21.

53. Idalene F. Kesner, Directors' Characteristics and Committee Membership: An Investigation of Type, Occupation, Tenure, and Gender, 31 ACAD. MGMT. J. 66, 67-68 (1988); see also David A. Carter, Frank D’Souza, Betty J. Simkins \& W. Gary Simpson, The Gender and Ethnic Diversity of US Boards and Board Committees and Firm Financial Performance, 18 Corp. Governance: InT'L Rev. 396, 400-01 (2010); April Klein, Firm Performance and Board Committee Structure, 41 J.L. \& ECON. 275, 277-80 (1998). 
committees are the audit committee, ${ }^{54}$ the nominating committee, ${ }^{55}$ the corporate governance committee, ${ }^{56}$ and the compensation committee ${ }^{57}$ Research has shown that directors have a stronger, more direct impact on executive compensation, new director selection, and other important board actions if they serve on board committees that are tasked with the primary responsibility for these functions. ${ }^{58}$ Consequently, accounting for a director's specific board committee membership provides a more accurate picture of the director's role on the board.

\section{B. Gender Diversity on Corporate Boards}

The board's importance as a corporate organ has led to increased scrutiny regarding its composition and structure. ${ }^{59} \mathrm{In}$ recent years, board gender diversity has become one of the biggest issues looming over corporate boardrooms, with some dubbing board composition as "the" issue of $2017 .{ }^{60}$ With State Street, Vanguard, and Blackrock voicing their commitment to this issue,${ }^{61}$ it is not surprising that in

54. The audit committee is charged with ensuring the quality and integrity of the company's financial statements and regulatory compliance. Under NYSE listing rules, the committee must be comprised solely of independent directors. See N.Y. Stock Exch., Section 303A.07 Audit Committee Additional Requirements, NYSE Listed Company Manual (Aug. 22, 2013), http://wallstreet.cch.com/LCMTools/PlatformViewer.asp?selectednode=chp_1_4 _3_8\&manual=\%2Flcm\%2Fsections $\% 2$ Flcm-sections $\% 2 \mathrm{~F}$ [https://perma.cc/L77T-PBCT].

55. The nominating committee is in charge of nominating director candidates and often also selects new CEOs and peer directors to the other board committees. See Joseph V. Carcello, Terry L. Neal, Zoe-Vonna Palmrose \& Susan Scholz, CEO Involvement in Selecting Board Members, Audit Committee Effectiveness, and Restatements, 28 CONTEMP. ACCT. RES. 396, 397-401 (2011).

56. The corporate governance committee is responsible for assisting a corporate board in matters related to the corporation's governance structure. DIRTT ENVTL. SOLS., CORPORATE GOvernANCE COMMitTEE CHARTER 2 (Oct. 17, 2013), https://www.dirtt.net/assets /attachments/59cdebe4e1/DIRTT-GovernanceCommittee-Jan18.pdf [https://perma.cc/7ZU9 $-\mathrm{BZCH}]$.

57. The compensation committee is tasked with setting the compensation of senior executives and generally oversees the corporation's compensation policies. Under NYSE listing rules the committee must be comprised solely of independent directors. See N.Y. Stock Exch., Section 303A.05 Compensation Committee, NYSE Listed CoMPANY MANUAL (Jan. 11, 2013), http://wallstreet.cch.com/LCMTools/PlatformViewer.asp?selectednode=chp_1_4_3 _6\&manual=\%2Flcm\%2Fsections\%2Flcm-sections\%2F [https://perma.cc/VD5A-BJRE].

58. See Klein, supra note 53, at 279-80.

59. See, e.g., Marc S. Gerber, US Corporate Governance: Boards of Directors Face Increased Scrutiny, SKADDEN (Jan. 16, 2014), https://www.skadden.com/insights /publications/2014/01/us-corporate-governance-boards-of-directors-face-i [https://perma.cc /WNN5-2QSM]; Robert Hauswald \& Robert Marquez, Governance Mechanisms, Corporate Disclosure, and the Role of Technology 1-2 (Mar. 22, 2005) (unpublished manuscript), https:// papers.ssrn.com/sol3/papers.cfm?abstract_id=687138 [https://perma.cc/7YQJ-SGFM].

60. Paula Loop, A Look at Board Composition: How Does Your Industry Stack Up?, HARV. L. SCH. F. CORP. GOVERNANCE \& FIN. REG. (Mar. 6, 2017), https://corpgov.law.harvard .edu/2017/03/06/a-look-at-board-composition-how-does-your-industry-stack-up [https:// perma.cc/53UW-DCDLa].

61. See supra note 10 and accompanying text. 
2017 the number of board diversity proposals reached an all-time high. ${ }^{62}$ These proposals are also gaining stronger support from investors, with many large institutions voting in favor of such proposals. ${ }^{63}$ Proxy advisors have also shown support for the issue. ISS Analytics, a leading shareholder advisory firm, recommended that shareholders vote "for" all but two of the diversity proposals voted on in 2017. ${ }^{64}$ Furthermore, diversity proposals that were voted on received, on average, $28.3 \%$ of votes cast, which is a strong level of support in the context of social responsibility proposals. ${ }^{65}$ Moreover, the support level for diversity proposals has increased significantly, compared to 2016 where only $19.1 \%$ of votes cast supported these resolutions, with $28.3 \%$ of such proposals in 2017 receiving majority support and many more that settled prior to a vote. ${ }^{66}$

Most of these proposals requested that the board increase the diversity of its candidate pools, provide reports on actions taken by the board to increase diversity, or both. ${ }^{67}$ Additionally, the California State Teachers Retirement System

62. See Ronald O. Mueller \& Elizabeth Ising, Shareholder Proposal Developments During the 2017 Proxy Season, Harv. L. Sch. F. Corp. Governance \& Fin. Reg. (July 12, 2017), https://corpgov.law.harvard.edu/2017/07/12/shareholder-proposal-developments -during-the-2017-proxy-season [https://perma.cc/F2NJ-QGGF] ("Thirty-five proposals calling for the adoption of a policy on board diversity or a report on steps to increase board diversity were submitted in 2017 as compared to 28 proposals submitted in 2016. As in 2016, a substantial number of board diversity proposals were withdrawn, likely due to commitments made by companies to the proponents of these proposals, such as adopting board recruitment policies inclusive of race and/or gender."); see also Jeff Green \& Emily Chasan, Investors Push Corporate Boards to Add Women, People of Color, Bloomberg (Mar. 2, 2017, 10:49 AM), https://www.bloomberg.com/news/articles/2017-03-02/shareholders-target-pale-male -and-stale-corporate-boards [https://perma.cc/YC27-9GEV] (noting that according to ISS Analytics, 2017 shareholder proposals regarding diversity are on pace to meet or exceed the number of similar proposals from 2016).

63. For example, on April 27, 2017, a shareholder proposal to add women and minorities to the board at Cognex Corp. received $62.8 \%$ support with major institutional investors voting in favor. Among the supporters were Allianz, AXA Investment Managers, Florida State Board of Administration, State of Wisconsin Investment Board, Vanguard, BNY Mellon, and T. Row Price Associates Cognex Corporation: Proposal Summary, Proxy Insight (2017).

64. Mueller \& Ising, supra note 62 (noting that according to ISS Analytics, 2017 shareholder proposals regarding diversity are on pace to meet or exceed the number of similar proposals from 2016).

65. Id. Most shareholder proposals regarding social aspects get less than one-third of the votes with many barely crossing the $10 \%$ support level. Therefore, close to $30 \%$ support level is in fact large, and many companies, once such proposals receive these levels of support, further engage with shareholders to achieve a negotiated agreement. See Kobi Kastiel \& Yaron Nili, In Search of the "Absent" Shareholders: A New Solution to Retail Investors Apathy, 41 DEL. J. CORP. L. 55, 77-78 (2016) (discussing the 30\% support level and company engagement with shareholders).

66. Mueller \& Ising, supra note 62; see also David A. Katz \& Laura A. McIntosh, Corporate Governance Update: Prioritizing Board Diversity, HARv. L. SCH. F. CORP. GOVERNANCE \& FIN. REG. (Jan. 30, 2017), https://corpgov.law.harvard.edu/2017/01/30 /corporate-governance-update-prioritizing-board-diversity [https://perma.cc/EH3F-RVCY].

67. Green \& Chasan, supra note 62; Arthur H. Kohn, Elizabeth K. Bieber \& Maria I. Maldonado, Board Diversity Developments, HARV. L. SCH. F. CORP. GovernANCE \& Fin. REG. 
("CalSTRS") submitted letters to 125 California corporations without female directors strongly suggesting the inclusion of women on the board. ${ }^{68}$ Subsequently, thirty-five of these boards added at least one female to their boards. ${ }^{69}$

Yet, while $86 \%$ of directors participating in PwC's annual director survey stated they felt that women should comprise between $21 \%$ and $50 \%$ of the board, ${ }^{70}$ only $28 \%$ of Russell 3000 boards have more than one-fifth of their board comprised of women. ${ }^{71}$ Indeed, as of October 2017, on average, women comprise $16.2 \%$ of Russell 3000 boards. $^{72}$ The outlook is slightly better at the larger companies where women represent $20.8 \%$ of directors on Fortune 1000 boards. $^{73}$

Further, some boards in the United States have failed to even attempt to promote gender diversity. ${ }^{74} \mathrm{~A}$ recent report noted that of the 1500 largest Russell 3000 companies, seventy-six companies failed to have any female directors over the past decade..$^{75}$ An additional thirteen companies added a female director for the first time in $2016 .{ }^{76}$

At this current rate, projections show that corporate boards will not reach gender parity until 2055. ${ }^{77}$ In reaction to this slow growth, groups such as the Thirty Percent Coalition $^{78}$ and 2020 Women on Boards have organized in an attempt to increase female board participation at an even quicker rate. ${ }^{79}$ These organizations seek to

(Aug. 21, 2018), https://corpgov.law.harvard.edu/2018/08/21/board-diversity-developments [https://perma.cc/6GDZ-6MFW]. See generally RAJEEV KumAR, GEORGESON, 2016 ANNUAL CORPORATE GOVERNANCE REVIEW (2016), https://www.georgeson.com/us/Documents/acgr /acgr2016.pdf [https://perma.cc/7KPL-2BCA]. Though influential institutional investors such as the California Public Employees Retirement System ("CalPERS") strongly support such proposals, some fund managers prefer to vote against such proposals and engage directly with the board. See, e.g., Green \& Chasan, supra note 62.

68. Katz \& McIntosh, supra note 66.

69. Id.

70. PwC, PwC's 2016 Annual Corporate Directors Survey 6 (Oct. 2016), https:// www.pwc.com/us/en/governance-insights-center/annual-corporate-directors-survey/assets /pwc-2016-annual-corporate--directors--survey.pdf [https://perma.cc/V4RM-FRXC].

71. MARCEC, supra note 17.

72. See id.

73. 2020 Women On BDS., Gender Diversity IndeX: 2011-2017 Progress OF WoMen Corporate Board Directors by Company, Size, State and Sector 1 (2017), https://www.2020wob.com/sites/default/files/2020WOB_GDI_Report_2017_FINAL.pdf [https://perma.cc/S7R3-BRA4].

74. See Lublin, supra note 17.

75. Id.

76. Id.

77. Green \& Chasan, supra note 62.

78. "The mission of the Thirty Percent Coalition is to promote gender diversity, including women of color, on corporate boards. ... [F]ollowing the Coalition's Institutional Investors' initiatives more than more than [sic] 180 companies have appointed a woman to their boards and, in many instances, a woman of color. The Coalition's investors represent more than $\$ 3.5$ trillion in assets under management and continue to have a major impact." THIRTY PERCENT COALITION, https://www.30percentcoalition.org [https://perma.cc/6N86-FU2F].

79. The organization 2020 Women on Boards seeks to make all boards composed of at least twenty percent women by the year 2020. 2020 WOMEN ON BOARDS, https://www .2020wob.com [https://perma.cc/KV6Q-LGHJ]. 
refocus the criteria considered for directorships to increase the number of women considered for these positions. ${ }^{80}$

One of the key hurdles to improving diversity is the low turnover of directors. If companies appoint new directors infrequently, the ability to increase the gender diversity of the board is significantly reduced. ${ }^{81}$ Aside from the refreshment problem, lack of leadership experience is often cited as one of the main barriers to increased gender diversity in the boardroom..$^{82}$ Because women, as well as minorities, have yet to hold leadership positions within corporate America on the same scale and level as white men, this prerequisite for nomination limits the number of diverse candidates. ${ }^{83}$

Because many companies seek operational and executive experience in their board nominees in order to raise investor confidence in the board, the underrepresentation of female executives in corporate America also limits the opportunities available to women to serve as directors. ${ }^{84}$ However, the limited pool argument does not seem to explain the current disparities. ${ }^{85}$ Further building on the issue is the limited ability to network or add meaningful director experience for women. ${ }^{86}$ As this Article will later develop, a majority of directors serve on multiple boards. Whether due to the same nomination criteria, the ability to network within boards, or the additional qualification of prior experience, the limited number of upper-management positions held by women severely limits the growth in gender diversity within the boardroom.

\section{The Two-Headed Case for Gender Diversity on Corporate Boards}

Why does gender diversity in boardrooms matter, and what are the justifications supporting investors and regulators' push for a change in board composition? These questions are at the core of the gender diversity debate. Broadly, the push for gender

80. See How To Find Qualified Women to Serve on Corporate Boards, 2020 WoMEN ON BOARDS, https://www.2020wob.com/learn/how-find-qualified-women-serve-corporate -boards [https://perma.cc/BB86-4RM8]; Who We Are, ThiRTy PERCEnt CoAlition, https://www.30percentcoalition.org/who-we-are [https://perma.cc/V6FJ-7P9W].

81. See, e.g., DHIR, supra note 20, at 44; Nili, supra note 52, at 139.

82. Deborah L. Rhode \& Amanda K. Packel, Diversity on Corporate Boards: How Much Difference Does Difference Make?, 39 DEL. J. CORP. L. 377, 402 (2014); see also DHIR, supra note 20 , at $38-46$.

83. See Lisa M. Fairfax, Clogs in the Pipeline: The Mixed Data on Women Directors and Continued Barriers to Their Advancement, 65 MD. L. REv. 579, 599-601 (2006) [hereinafter Fairfax, Clogs in the Pipeline].

84. See DHIR, supra note 20, at 40 (stating the "CEO experience has become 'a quick litmus test for qualified board candidates"” (internal citation omitted)).

85. See Amanda K. Packel, Government Intervention into Board Composition: Gender Quotas in Norway and Diversity Disclosures in the United States, 21 STAN. J.L. Bus. \& Fin. 192, 198-200 (2016) (reviewing Aaron A. Dhir, Challenging BoArdroom Homogeneity: Corporate LAw, GOVERnANCE, AND Diversity (2015)).

86. A 2012 study of 1000 directors from fifty-eight countries found that while men tend to attribute lack of diversity to a "small pool" argument, women mostly attributed it to the male network argument. See Heidrick \& Struggles, 2012 BoArd of Directors Survey 3 (2012). 
diversity on boards rests on two distinct pillars. The first is grounded in social cause. The second makes an instrumental case for gender diversity.

\section{The Social Cause Case for Gender Diversity}

The social cause case for gender diversity is rooted in the larger gender equality, antidiscrimination, and feminist movement of the $1960 \mathrm{~s} .{ }^{87}$ Gender diversity on boards provides equal opportunity to women who historically were excluded from positions of power. Advocates of board gender diversity - like advocates of gender equality in other sectors - therefore rely on moral or social justifications in their push for gender diversity on the board.

Their case is premised on the intrinsic notion that increasing diversity is the "right thing to do," ${ }^{88}$ predominantly because the efforts to improve diversity are aimed at correcting the lingering effects of discrimination. ${ }^{89}$ "There is a strong public interest in ensuring that opportunities are available to all, ... that women entering the labo[]r market are able to fulfil their potential, and that we make full use of the wealth of talented women" available for board service. ${ }^{90}$

Accordingly, some scholars argue that the rationale for improving diversity should reside in the justifications related to social benefits and duties. ${ }^{91}$ That is, social justice, equal opportunity, and corporate reputation should be enough to promote gender diversity within the board. ${ }^{92}$ Indeed, this social argument seems to carry some weight even within boards themselves. ${ }^{93}$ However, historically, advocacy efforts based solely on moral and social justice justifications have mostly failed to gain much traction with Main and Wall Street investors, leaving boards free to maintain their male-dominated composition. ${ }^{94}$

87. See DHIR, supra note 20, at 58; see also Lisa M. Fairfax, Some Reflections on the Diversity of Corporate Boards: Women, People of Color, and the Unique Issues Associated with Women of Color, 79 St. JoHN's L. REv. 1105, 1109 (2005).

88. Lisa M. Fairfax, Board Diversity Revisited: New Rationale, Same Old Story?, 89 N.C. L. REv. 854, 856-57 (2011) [hereinafter Fairfax, Same Old Story].

89. Id.; see also J. Cunyon Gordon, Painting by Numbers: “And, Um, Let's Have a Black Lawyer Sit at Our Table”, 71 FordHAM L. REV. 1257, 1277 (2003) (describing a university president's attitude that diversity is just "the right thing to do"); Vance Knapp \& Bonnie Kae Grover, Note, The Corporate Law Firm-Can It Achieve Diversity?, 13 NAT'L BLACK L.J. 298, 303 (1993) ("Law firms should hire more minority attorneys, of course, for reasons of simple justice."); David B. Wilkins, From "Separate Is Inherently Unequal” to "Diversity Is Good for Business": The Rise of Market-Based Diversity Arguments and the Fate of the Black Corporate Bar, 117 HARV. L. REV. 1548, 1553 (2004).

90. House of Lords [H.L.], Eur. Union COMM., WOMEn ON BoARds: Report 13-14 (Nov. 9, 2012) (U.K.).

91. Rhode \& Packel, supra note 82, at 395-401; see also DHIR, supra note 20, at 64-68.

92. Rhode \& Packel, supra note 82 , at 424.

93. As noted in the PwC study, almost eighty-three percent of directors feel that having females represent more than twenty percent is a good thing both commercially and morally. Yet, as seen in the same study and in practice, even coupled with the business case for diversity, the number of women on boards has yet to materialize to these numbers. PwC, supra note 70 , at 6 .

94. Fairfax, Same Old Story, supra note 88, at 855-57. 


\section{The Instrumental Case for Gender Diversity}

In recent years, many gender diversity advocates have shifted the core of their advocacy from social and moral justifications to a more instrumental case for diversity. ${ }^{95}$ This second pillar is focused on the benefits that gender-diverse boards provide to companies and investors and therefore on the "corporate governance case" for improving diversity on boards.

Two rationales exist to explain the instrumental value of gender-diverse boards. The first suggests that groups that are more diverse generally make better decisions. Studies have shown that a group of high-functioning diverse individuals tends to outperform a nondiverse group of the best performing individuals. ${ }^{96}$ The second rationale suggests that boards focused on gender diversity within the boardroom are also more likely to utilize talent pools more effectively and have a better understanding of the employee and customer bases, and that signaling that the company cares about diversity may be effective in bolstering economic arguments. ${ }^{97}$

The instrumental case for gender diversity encompasses a large spectrum of benefits. Broadly speaking, it could be divided into two main strands. The first focuses on corporate performance in its narrow sense- the corporate bottom line..$^{98}$ The second focuses on performance in the broader sense-the way boards work, group dynamics, risk taking, accounting integrity, and other less quantifiable governance measures. ${ }^{99}$

\section{a. Bottom Line Performance}

A growing body of studies has linked gender-diverse boards and improved corporate performance. ${ }^{100}$ For example, MSCI conducted a study in 2015 to test the hypothesis that increased gender diversity within the boardroom correlates with increased corporate performance for that year. ${ }^{101}$ This study analyzed companies with "strong female leadership." 102 In 2016, it conducted a similar study, however,

95. See DHIR, supra note 20, at 58-64; Fairfax, Same Old Story, supra note 88, at 88485.

96. See, e.g., Lu Hong \& Scott E. Page, Groups of Diverse Problem Solvers Can Outperform Groups of High-Ability Problem Solvers, 101 Proc. NAT'L ACAD. SCI. U.S. 16385, 16389 (2004).

97. See Packel, supra note 85, at 217-18. Importantly, more women in the boardroom is also associated with more women in senior management positions and below. Similar to boardroom gender diversity, gender diversity within senior levels of management correlates with better company performance, and female board member participation may pave the way for a more gender diverse management. $I d$.

98. See JoY ET AL., supra note 8.

99. See Packel, supra note 85, at 200-04; see also DHIR, supra note 20, at 58-64; Fairfax, Same Old Story, supra note 88, at 879-90; Rhode \& Packel, supra note 82, at 393-401.

100. See Meggin Thwing Eastman, Daimon Rallis \& Gaia Mazzucchell, MSCI, The TipPing Point: Women on Boards And Financial Performance 6-8 (2016).

101. Id.

102. Id. "Strong female leadership" was categorized as a company having a female CEO and at least one woman on the board, three or more women on the board, or a higher than country average percentage of women on the board. Id. at 6 n.6. 
this time analyzing returns over a five-year period and separating companies into those that reached the "tipping point" of women in the boardroom with those with no women on the board. ${ }^{103}$ Thus, the MSCI study attempted to test whether having this critical mass positively impacted company performance. ${ }^{104}$ Both studies returned the same result: companies with "strong female leadership" enjoyed better rates of return than their counterparts without a female board director. ${ }^{105}$

These recent studies join earlier studies finding a relationship between gender diversity and performance. ${ }^{106}$ Referencing these studies allows gender diversity supporters to "pitch" their concerns to an otherwise skeptical public. ${ }^{107}$

However, the business case in its narrowest sense-a positive effect on accounting measures or stock price- - has yet to definitively establish that gender diversity is the cause of an increase in the bottom line. ${ }^{108}$

Linking corporate performance to specific board attributes is inherently difficult, and therefore it is not surprising that the case for bottom line performance has produced a mixed bag of empirical results. First, while positive correlations have been seen with increased gender diversity, researchers acknowledge that "correlation does not imply causation." ${ }^{109}$ For example, the recent MSCI studies failed to

103. Id. at 6-7. The theory behind the "tipping point" is that having three or more similar "minorities" within a group provides a critical mass to present opposing and additional viewpoints. Id. By reaching this number, the gender parity on the board is seen as an actual change as opposed to the mere ability to state that the board itself is diverse. However, the study does not provide evidence that merely having one or two female directors does not positively affect corporate performance as well. $I d$. at 11 .

104. See id. at 15.

105. Id. at 3. Companies with "strong female leadership" had a Return on Equity (ROE) of $10.1 \%$ whereas companies without female directors had a ROE of $7.4 \%$. Id. at 3 . The 2016 five-year study narrowed the focus to U.S. companies, and the results suggested an even more drastic discrepancy between companies who had reached the "tipping point" of female board inclusions and those without a female director. The "tipping point" group had a median ROE of $10 \%$ and an Earnings Per Share (EPS) increase over the time period of $37 \%$. Id. The group devoid of female directors, on the other hand, had a ROE of $1 \%$ and an EPS of $-8 \%$. Id.

106. See Rhode \& Packel, supra note 82, at 383-93.

107. See Catalyst, 2007 Census: Board Directors at 1 (2007), https://www .catalyst.org/system/files/census_board_final.pdf; Fairfax, Same Old Story, supra note 88, at 860-65 (addressing the business rationales for diversity and arguing that diversity advocates must pay greater attention to the role of social and moral justifications in the effort to diversify the corporate boardroom); Lisa M. Fairfax, The Bottom Line on Board Diversity: A CostBenefit Analysis of the Business Rationales for Diversity on Corporate Boards, 2005 WIs. L. REV. 795, 810-38 (2005) (evaluating the different business rationales for board diversity and the risks they may entail).

108. See Renée B. Adams \& Daniel Ferreira, Women in the Boardroom and Their Impact on Governance and Performance, 94 J. FIN. ECON. 291, 308 (2009) ("Although a positive relation between gender diversity in the boardroom and firm performance is often cited in the popular press, it is not robust to any of our methods of addressing the endogeneity of gender diversity."); Rhode \& Packel, supra note 82, at 383-93 (reviewing the issues with the narrow business case for diversity and discussing the explanations for the varied results).

109. See, e.g., Darren Rosenblum \& Daria Roithmayr, More than a Woman: Insights into Corporate Governance After the French Sex Quota, 48 IND. L. REV. 889, 902-03 (2015) (noting that most studies caution that evidence of a causal relationship is "suggestive rather 
establish a statistically significant causal link between the presence of women and their performance metrics. ${ }^{110}$

Second, despite the recent wave of studies supporting a positive correlation between gender diversity and bottom line performance, other conflicting studies show that diverse boards fail to truly outperform the market ${ }^{111}$ and that there had been a drop in corporate performance after the initiation of a quota in certain countries. ${ }^{112}$ These findings, and the difficulties inherent in linking corporate performance to specific board attributes, have led some scholars and gender equality advocates to refocus the instrumental case on corporate performance in its broader sense. ${ }^{113}$

\section{b. Board Dynamics and Governance}

Empirical evidence on board processes and socio-psychological research on small-group dynamics have supported the argument that diverse boards are associated with better decision-making and governance. ${ }^{114}$ The basic premise of these arguments is that diversity - whether through representation of different strengths, consideration of different concerns, or questions based on varying life

than conclusive"); see also Virtcom Consulting, Board Diversification Strategy: Realizing Competitive Advantage And Shareholder Value 4-5 (2009).

110. See Adams \& Ferreira, supra note 108, at 308 (discussing the lack of a causal link); EASTMAN ET AL., supra note 100 (discussing the MSCI studies).

111. See Virtcom Consulting, supra note 109, at 10. The Virtcom Consulting study shows that over a five-year period, diverse boards outperformed the NASDAQ 100 and the Dow Jones Industrial Average but failed to outperform the Standard \& Poor's 500. Id. Because the NASDAQ 100 and Dow Jones incorporate only some of the largest firms, it begs the question of how to establish the proper benchmark for analyzing gender diversity. Additionally, it raises the issue of properly segmenting the different types of companies between diverse and not diverse.

112. See, e.g., Rosenblum \& Roithmayr, supra note 109. Albeit this is perhaps due to the need for boards to dip into younger, less-qualified talent pools for the same number of women. See Kenneth R. Ahern \& Amy K. Dittmar, The Changing of the Boards: The Impact on Firm Valuation of Mandated Female Board Representation, 127 Q.J. Econ. 137, 188 (2012).

113. See DHIR, supra note 20, at 64-68; Rhode \& Packel supra note 82, at 390-93.

114. See Vicki W. Kramer, Alison M. Konrad \& Sumru Erkut, Critical Mass on Corporate Boards: Why Three or More Women Enhance Governance 8-9 (Wellesley Ctrs. For Women, Working Paper No. 11, 2006). But cf. Scott E. Page, The DifFerence: How the Power of Diversity Creates BetTer Groups, Firms, Schools, AND Societies 324-35 (2007); Lynne L. Dallas, The New Managerialism and Diversity on Corporate Boards of Directors, 76 TuL. L. REV. 1363, 1391 (2002) (explaining that "heterogeneous groups do not necessarily have an advantage over homogeneous groups when the task is solving problems that have verifiably, correct answers"); Frank Dobbin \& Jiwook Jung, Corporate Board Gender Diversity and Stock Performance: The Competence Gap or Institutional Investor Bias?, 89 N.C. L. REV. 809 , 814-15 (2011); Cass R. Sunstein, Deliberative Trouble? Why Groups Go to Extremes, 110 YALE L.J. 71, 111-12 (2000). 
experiences-will counteract groupthink. ${ }^{115}$ Indeed, there has been a growing body of evidence that diversity on boards is associated with improved governance. ${ }^{116}$

Some legal studies have also attempted to quantify the personal impact of gender diversity within the boardroom through interviews with former corporate directors. ${ }^{117}$ Through these studies, scholars have noted two almost unanimous observations. First, directors believe that board diversity is important and boards should attempt to improve diversity. ${ }^{118}$ Second, when pressed for tangible examples of how gender diversity made a difference, respondents struggled to provide responses. ${ }^{119}$ These findings further crystalize the difficulty in directly attributing the benefits of diversity.

Finally, gender diversity can have a positive impact on the monitoring role of the board. ${ }^{120}$ According to a study of the Norwegian quota regime, female directors tend to bring to the boardroom a more vigilant and probing approach, and women "may be particularly adept at critically questioning, guiding, and advising management without disrupting the overall working relationship between the board and management.". 21 Similarly, a study of Israeli boards found that "[b]oards with at least 3 directors of each gender are found to be at least $79 \%$ more active at board meetings than those without such representation" and that "[g]ender-balanced boards are also more likely to replace underperforming chief executive officers (CEOs) and are particularly active during periods when CEOs are being replaced." 122

115. For example, studies have found evidence that women are more financially risk averse, more trustworthy, and more collaborative. See IRving L. JANIS, GRoupthink: Psychological Studies of Foreign-Policy Decisions and Fiascoes 9 (2d ed. 1982) (defining groupthink as a phenomenon in which members' efforts to achieve consensus can override their ability to "realistically appraise alternative courses of action"); see also Marleen A. O'Connor, The Enron Board: The Perils of Groupthink, 71 U. CiN. L. REv. 1233, 1306-08 (2003) (discussing how diversity on corporate boards can discourage groupthink).

116. See Rhode \& Packel, supra note 82, at 393-401; see also Adams \& Ferreira, supra note 108, at 304 (finding that firms with higher proportions of female directors hold more meetings, have higher attendance rates, greater participation in decision making, engage in tougher monitoring, and are more likely to replace a CEO after poor stock performance); Fairfax, Clogs in the Pipeline, supra note 83, at 589-95; Sandeep Gopalan \& Katherine Watson, An Agency Theoretical Approach to Corporate Board Diversity, 52 SAN DIEGo L. REV. 1, 20 (2015) ("Some of the most persuasive evidence about the ability of diverse boards to improve firm performance concerns the role of the board in monitoring management."); Rosenblum \& Roithmayr, supra note 109, 927-28.

117. See Kimberly D. Krawiec, John M. Conley \& Lissa L. Broome, Diversity and Talent at the Top: Lessons from the Boardroom, in DiVERSITY IN PRACTICE: RACE, GENDER, AND Class in Legal and Professional Careers 81 (Spencer Headworth et al. eds., 2016).

118. However, the study did note one adamant dissenter. $I d$. at 82.

119. Id.; see also Kimberly D. Krawiec, John M. Conley \& Lissa L. Broome, The Danger of Difference: Tensions in Directors' View of Corporate Board Diversity, 2013 U. ILL. L. REV. 919, 920 (2013).

120. DHIR, supra note 20, at 35.

121. Id.

122. Miriam Schwartz-Ziv, Gender and Board Activeness: The Role of a Critical Mass, 52 J. Fin. \& QuANTITATIVE ANALYSIS 751, 751 (2017). 
In sum, moral and social reasons, corporate finance justifications, and corporate governance findings have all been raised to support the case for more gender diversity in boards.

\section{The Missing Dimension: Substantive Gender Diversity}

Academic and public discourse has too often focused on the idea of achieving some minimum representation of women-sometimes as few as one. ${ }^{123}$ Yet, increasing the number of women on boards is only a partial step in the achievement of a truly gender-diverse board. A truly diverse board gives women more than a seat at the table - it grants them the ability to have a voice and an impact. Therefore, academic and public discourse must also examine whether the roles that women are tasked with as directors afford them equal opportunity to make an impact.

The answer to this question requires a deeper, truer measure of gender equity. It is also central to both strands of gender diversity justifications, as it is a key component in the case they each make for advancing gender diversity. Indeed, as explained below, substantive gender diversity matters whether you believe that gender diverse boards perform better or whether you believe that women are entitled to equal treatment.

Clearly, if the motivation for better gender diversity on boards is rooted in the antidiscrimination notion, then ensuring equal treatment within the boardroom is as important a goal as ensuring that women get better representation on boards. If women are denied an equal voice and are shunned from leadership roles, they are denied equal treatment.

Advocates of the instrumental case for gender diversity must also turn their focus to the question of substantive gender diversity. If the presence of women on boards improves corporate performance, in its narrow or broader sense, then we must gain insight with respect to the ability of women to truly influence and transform the way boards work. Acknowledging the instrumental value that gender diversity brings to the board must necessarily also lead to an examination of the ways through which women are able to contribute to the board's work.

It is, therefore, imperative that gender diversity discourse turn its attention to the question of substantive diversity. Whether advocating for gender diversity out of a social cause agenda or due to the belief that diversity improves the board's work and therefore company performance, substantive diversity in the boardroom is an important dimension in ensuring such goals. Importantly, this Article does not stake a claim regarding the proper justification for gender diversity on boards. Rather, given the existing push for gender diversity, the Article underscores the import of the substantive data on gender diversity for current gender diversity discourse.

Despite the importance of substantive gender diversity, investors, regulators, and academic discourse have left this dimension unattended, focusing on the quantitative dimension instead. Redirecting the attention of gender diversity discourse to this important facet is the first goal of this Article.

But recognizing the value of substantive gender diversity also means that we need to know more on the current picture of the substantive diversity of boards in the

123. See supra notes 6-9 and accompanying text. 
United States. Furthermore, if differences do exist, we need to know why, and we need to understand the costs that these differences might cause. In the next Part, this Article takes a first step in informing the current academic discourse with novel findings regarding substantive gender diversity in boardrooms.

\section{GENDER DIVERSITY-EMPIRICAL FINDINGS}

This Part provides insight into the question of substantive diversity on boards by examining the substance of female directors' participation on boards relative to their male peers, as well as over time.

This study examines the S\&P 1500 companies during the years 2007 to 2015. ${ }^{124}$ Because the study spans multiple years, some companies moved into the index while other companies moved out. ${ }^{125}$ Thus, 1868 individual companies appear at least once throughout the sample period. ${ }^{126}$ The data for this sample was originally compiled from Wharton Research Data Services (WRDS) and was subsequently augmented with data from Bloomberg, FactSet, and Equilar BoardEdge. ${ }^{127}$ On average, there were 13,872 directors in each data year with an average of 11,980 male and 1892 female directors. ${ }^{128}$ Both descriptive statistics as well as regression models were used

124. The complete data file is with the author. Based on the data, the regression models analyzed the impact of year, market capitalization, age of the company, and industries on the dependent variables. This study looked at the timeframe spanning 2007 to 2015 , providing the ability to measure the change of any given variable throughout the study period. Market capitalization was measured in thousands of dollars as reported at the end of the calendar year. While each index represents a proxy for the size of any given company, market cap allows an evaluation on the size of a company on each variable. The age of the company was measured in years from the founding of the company. While the year provides information regarding the change in a given dependent variable, the age of the company attempts to look at the differences between older and newer companies. Finally, to limit the number of industries, the data were limited to the following classifications: Consumer Services, Electronic Technology, Finance, Industrial Services, Retail Trade, Technology Services, Utilities, and Other. The "Other" variable includes all companies within the study not included in any of the other industries and is the reference or baseline category in the multivariate regression models.

125. The S\&P U.S. Indices are a family of equity indices designed to measure the market performance of U.S. stocks trading on U.S. exchanges. The family is composed of a wide range of indices based on size, sector, and style. The indices are weighted by float-adjusted market capitalization and require unadjusted company market capitalization of US\$6.1 billion or more for the S\&P 500, $\$ 1.6$ billion to $\$ 6.8$ billion for the S\&P MidCap 400, and $\$ 450$ million to $\$ 2.1$ billion for the S\&P SmallCap 600. These ranges are reviewed from time to time to assure consistency with market conditions. See S\&P Composite 1500, S\&P Dow JoneS INDICES, https://us.spindices.com/indices/equity/sp-composite-1500 [https://perma.cc/KL3Z -GSPZ].

126. The ISS director data file within the WRDS database contains various statistics on directors in public companies in the United States. See About, Wharton, Univ. Pa., https://wrds-www.wharton.upenn.edu/pages/about [https://perma.cc/J8WS-ESZR].

127. Available data for each director: Data Year; Date Started; Age; Total Number of Male \& Female Directors; Number of Other Directorships; Company Industry; Market Capitalization; Title within the Company (if applicable); and whether the director was on the Audit, Compensation, Corporate Governance, or Nominating Committee. See id.

128. Id. 
in this study. The former provides insight into absolute and relative numbers whereas the latter shows how certain numbers or levels are impacted by other variables.

This Part begins with a presentation of the empirical findings regarding quantitative and substantive gender diversity in Sections A and B, respectively. Section $\mathrm{C}$ then ties the results together, underscoring the key lessons that can be derived from the findings.

\section{A. Quantitative Gender Diversity}

As a first step, this Section follows the prevalent "quantitative" approach to gender diversity, examining the current ratios and percentages of women on S\&P 1500 companies' boards, both across different companies and over time. These quantitative results are an important foundation, setting the stage for the substantive analysis that the study centers on in the following Section.

Overall, the S\&P 1500 followed a similar trend to the one seen in other indices with respect to the gender composition of boards. As a whole, the percentage of female directors on boards has increased from $11.9 \%$ in 2007 to $16.5 \%$ in 2015 . At the start of the study, the ratio of men to women was 7.4:1. This ratio decreased to 5.07:1 in 2015.

While during the study period more men were added to corporate boards than women, the rate of adding women to boards has increased over time. The retail industry has the top gender parity with $19.2 \%$ of directorships represented by women. On the other hand, Industrial Services and Electronic Technology lag behind other industries with only $7.7 \%$ and $8.9 \%$, respectively, of total female board participation.

Figure 1: Percentage of Female Board Directors in the $S \& P 1500$ by Year (2007-2015)

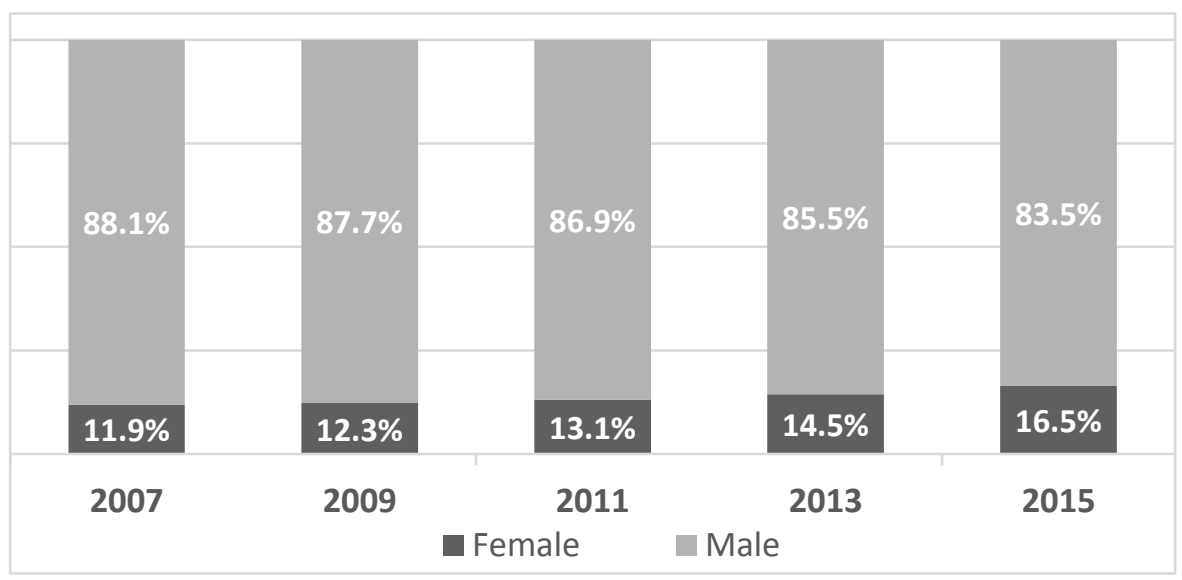

Table 1 presents regression results of the percentage of women on boards on several independent variables. The percentage of women increased on average by .5 percentage points for every additional year of the study. Additionally, the size of a company is positively correlated with better boardroom gender parity. That is, for every one-million-dollar increase in a company's market capitalization, the percentage of women on a board increased by .5 percentage points. Finally, older 
companies tend to have more women relative to their younger counterparts. For each additional year since formation, the percentage of women on a given board increased by .04 percentage points.

Table 1: Regression Results

\begin{tabular}{|l|l|l|l|}
\hline & \multicolumn{1}{|c|}{ Average } & \multicolumn{1}{|c|}{ Female Ratio } & \multicolumn{1}{|c|}{ Female Ratio } \\
\hline Year (2007 = Year 0) & 4.1 & $.005^{* * *}$ & $.005^{* * *}$ \\
\hline Market Cap (in thousands of \$) & 10112.34 & $4.54 \times 10^{-7 * * *}$ & $4.67 \times 10^{-7 * * *}$ \\
\hline Age of Company (years) & 17.02 & $.0005^{* * *}$ & $.0004 * * *$ \\
\hline Consumer Services (industry) & .149 & & $.021^{* * *}$ \\
\hline Electronic Technology (industry) & .089 & & $-.039^{* * *}$ \\
\hline Finance (industry) & .133 & & $.006 * *$ \\
\hline Industrial Services (industry) & .077 & & $-.050^{* * *}$ \\
\hline Retail Trade (industry) & .192 & & $.051 * * *$ \\
\hline Technology Services (industry) & .105 & & $-.026^{* * *}$ \\
\hline Utilities (industry) & $.191 * * *$ & & $.058^{* * *}$ \\
\hline Constant & & $.095 * * *$ & $.096 * * *$ \\
\hline $\mathrm{N}$ & 12,167 & 12,167 & 12,167 \\
\hline $\mathrm{R}^{2}$ & & .0549 & .1152 \\
\hline
\end{tabular}

Table 1: This Table presents the results from ordinary least squares (OLS) regressions where the dependent variable is female board percentage. The first column presents the averages for each independent variable. Industry averages are proportions. The second column presents OLS results for Year, Market Cap, and Age. The third column presents regression results after accounting for industry. $* * *(* * *)$ indicates statistical significance at the $1 \%(5 \%, 10 \%)$ levels.

These results confirm the conclusions of previous studies, showing a general trend towards increased board gender diversity, at least as measured by the ratio of men to women. Importantly, the results also highlight that significant differences between companies exist, depending on industry, size, and age of the company. These differences are often underexplored in current scholarship.

\section{B. Substantive Gender Diversity}

This Section starts where prior studies have ended, examining a set of substantive measures of gender diversity in the boardroom. These variables are important factors when determining the level of parity that female directors enjoy.

By examining all available information from the compiled data regarding the age, tenure, leadership roles, service on other boards and specific workload, and responsibilities within the boardroom, this Section sheds light on observed differences between male and female directors. Importantly, while many unobserved dynamics may influence board parity, this study has narrowly focused on observable metrics. In part, the focus stems from lack of available data regarding unobserved board dynamics. Yet, it is also shaped by the practical need for measurable substantive variables that can be easily and neutrally collected and compared. 


\section{Tenure}

Director tenure has become an important factor in corporate governance. ${ }^{129}$ Yet, while most studies look at director tenure as a whole, the relative tenure of men and women could be important in the context of substantive gender diversity. If companies appoint more women but retain them for shorter tenures than their male counterparts, this could counteract the increased representation of women on the board. Particularly, shorter tenure may limit the ability of a director to gain clout within the boardroom, and the company, and marginalize her vis-à-vis the longer tenured male directors in the room. If men and women have significant and systematic differences in their tenure, a concern may arise as to the true level of substantive equality in the boardroom.

As shown in Table 2, the data indeed reveals systemic differences in the tenure of men and women. In total, men had an average tenure of between $1.99(22 \%)$ and 2.64 $(27 \%)$ years longer than women. This overall disparity is more than a byproduct of recent board appointments for more women as it has persisted over time, across measures of industry and market size. ${ }^{130}$

Table 2: Average Tenure Length by Gender and Year (2007-2015)

\begin{tabular}{|l|l|l|l|l|l|l|l|l|l|}
\hline & 2007 & 2008 & 2009 & 2010 & 2011 & 2012 & 2013 & 2014 & 2015 \\
\hline Female & 6.87 & 7.14 & 7.48 & 7.60 & 7.73 & 7.80 & 7.79 & 7.67 & 7.42 \\
\hline Male & 9.22 & 9.38 & 9.47 & 9.67 & 9.84 & 10.03 & 10.04 & 10.06 & 10.06 \\
\hline Difference & 2.35 & 2.24 & 1.99 & 2.07 & 2.12 & 2.23 & 2.25 & 2.39 & 2.64 \\
\hline
\end{tabular}

In 2007, women had an average tenure of 6.87 years. This number increased to 7.8 years in 2012, but subsequently fell to 7.42 in 2015 . Men, on the other hand, had an average tenure of approximately 10 years from 2012 to 2016. Figure 2 shows that differences between men and women are even starker as one moves from the S\&P 500 (large-cap companies) to the S\&P 400 (mid-cap) and subsequently to the S\&P 600 (small-cap). The difference in 2015 between men and women for the S\&P 500 was 1.94 years (9.61 years versus 7.67 years). In the S\&P 400 and S\&P 600, the differences were 3.06 years (10.27 versus 7.21$)$ and 3.15 years (10.36 versus 7.21 ) respectively. This suggests that the gap between men and women is much closer in larger companies.

129. See Nili, supra note 52 (discussing the impact of director tenure on corporate governance).

130. Importantly, the median tenure of women is two years lower than that of men, even during the last few years. The standard deviation of the tenure of women has also not changed dramatically, reducing the concern that the disparity is driven by the recent influx of women to boardrooms. 
Figure 2: Gap in Average Tenure of Male vs. Female Board Members

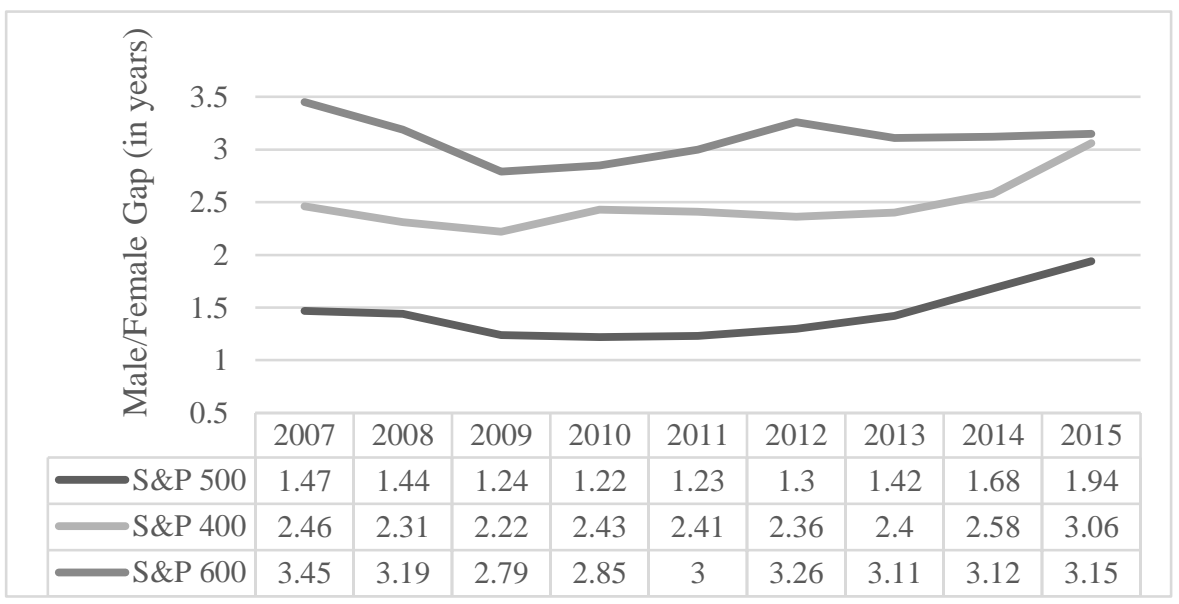

Looking at the difference in the tenure of female directors across industries, Utilities had the longest tenured women at an average of 8.39 years of service. Technology Services represents the shortest average tenure of female directors with an average of only 5.57 years of service. According to the regression results displayed in Table 3, even after controlling for age of the company under the assumption that companies in the Utilities Industry are older than Technology Services, these two industries remained at the extremes of the tenure spectrum.

Table 3: Regression Results

\begin{tabular}{|c|c|c|c|}
\hline & Average & $\begin{array}{c}\text { Female } \\
\text { Tenure Length }\end{array}$ & $\begin{array}{c}\text { Female } \\
\text { Tenure Length }\end{array}$ \\
\hline Year $(2007=$ Year 0) & 4.26 & $.035^{*}$ & $.039 * *$ \\
\hline Market Cap (in thousands of \$) & 12733.04 & $5.73 \times 10^{-7}$ & $1.5 \times 10^{-6}$ \\
\hline Age of Company (years) & 18.6 & $.034 * * *$ & $.034 * * *$ \\
\hline Consumer Services (industry) & 7.419 & & -.221 \\
\hline Electronic Technology (industry) & 6.597 & & $-1.167 * * *$ \\
\hline Finance (industry) & 7.681 & & .135 \\
\hline Industrial Services (industry) & 6.472 & & $-1.193 * * *$ \\
\hline Retail Trade (industry) & 7.230 & & $-.566 * * *$ \\
\hline Technology Services (industry) & 5.570 & & $-2.122 * * *$ \\
\hline Utilities (industry) & 8.397 & & .180 \\
\hline Constant & & $6.70 * * *$ & $6.929 * * *$ \\
\hline $\mathrm{N}$ & & 9,038 & 9,038 \\
\hline $\mathrm{R}^{2}$ & & .0216 & .0354 \\
\hline
\end{tabular}

Table 3: This Table presents results from OLS regressions where the dependent variable is female tenure length. The first column presents averages for each independent variable. The second column presents OLS results for Year, Market Cap, and Age. The third column presents results after accounting for industry. $* * *(* *, *)$ indicates significance at the $1 \%(5 \%, 10 \%)$ levels. 


\section{Age}

Age disparity between groups of directors might affect different boards in various ways. In some cases, boards may enjoy the added level of age heterogeneity while in others age disparity may be a cause of friction. Figure 3 presents the observed information regarding the gender and age disparity. Until 2015, when the average age of women serving on corporate boards decreased (likely due to the increased additions of women), the average age of directors of both genders steadily increased throughout the study period. On average, male directors tended to be older than their female counterparts. In 2007, the difference between men and women was 4.38 years (61.86 versus 57.48 ). This difference shrank substantially to 2.49 years in 2014, but rose again in 2015. As of 2015 male directors were on average 64 years old while female directors were, on average, 60.51 years old. Looking at women individually, the average director was older in the large cap companies, but little difference exists between mid- and small-cap stocks.

Figure 3: Average Age of Directors by Gender and Year (2007-2015)

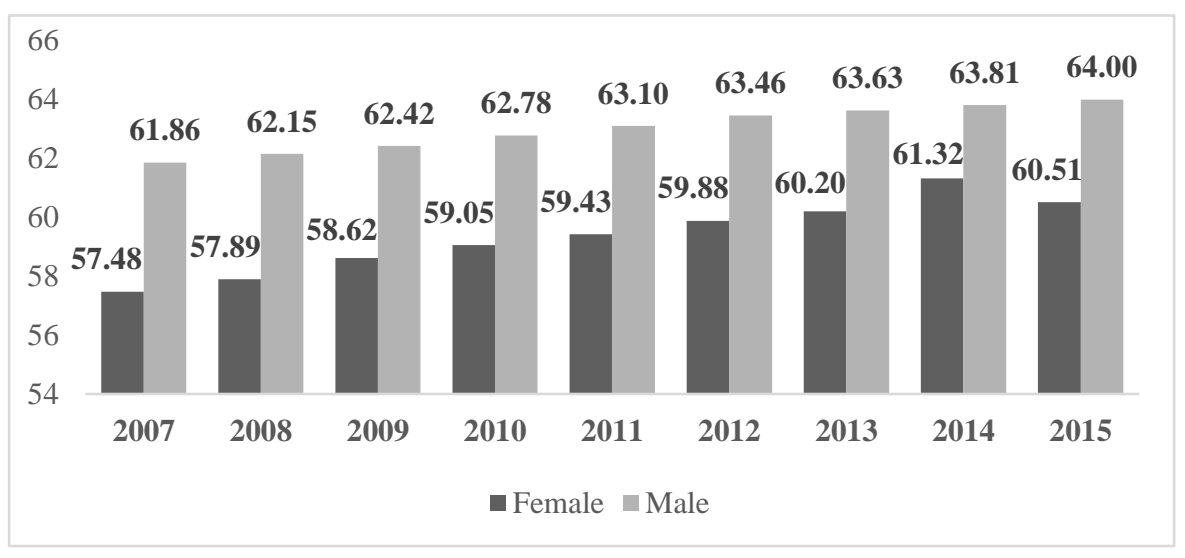

\section{Chair Positions}

A key indicator for influence in the boardroom is the position of the chair of the board. As chair, a director has control of the board's agenda in addition to other formal and informal powers. ${ }^{131}$ While in many companies the CEO is also the chairperson of the board, recent trends have led to a separation of these roles with many companies appointing independent directors as board chair. ${ }^{132}$

131. For a discussion of the chair's role, see, for example, Stanislav Shekshnia, How to Be a Good Board Chair, HARv. Bus. REV., Mar.-Apr. 2018, https://hbr.org/2018/03/how-to-bea-good-board-chair [https://perma.cc/ECM2-YWBD].

132. See Ryan Krause, Mike Withers \& Matthew Semadeni, Sharing the Lead: Examining the Causes and Consequences of Lead Independent Director Appointment, HARV. L. SCH. F. CorP. Governance \& Fin. REG. (Sept. 20, 2017), https://corpgov.law.harvard.edu/ 2017/09/20/sharing-the-lead-examining-the-causes-and-consequences-of-lead-independentdirector-appointment [https://perma.cc/9E5N-VLQL]. 
Examining the ratio of men to women as non-CEO chairs of boards, ${ }^{133}$ while controlling for their relative size, the data show a significant disparity between female and male directors. First, in absolute numbers the differences are striking. In 2015, there were only 27 female directors who served as chair compared to 769 males. As a ratio of the total number of directors, the disparity is still striking. Women serving as chairwoman were only $1 \%$ out of the entire female director sample, while men were six times more likely to serve as chairman, standing at $6.5 \%$ of the male director sample. ${ }^{134}$

\section{Lead Independent Director Role}

When the CEO also serves as the chair of the board, or when the chair is not an independent director, many companies name a "lead independent director." This director has a leadership role among the independent directors on the board and often serves as counterweight to the CEO/Chair. ${ }^{135}$ Examining the ratio of men to women serving as lead independent directors, while controlling for their relative size, the data, again, show significant disparity between the genders. In 2015, only 57 female directors served as lead independent directors compared to 539 males. As a ratio of the respective total number of directors, women serving as lead independent directors were only $3.6 \%$ out of the entire female director sample, while men were more than two times more likely to serve as lead directors, standing at $7.4 \%$ of the male sample.

Table 4: Lead Independent Director Role

\begin{tabular}{|l|l|l|l|l|l|l|l|}
\hline & $\begin{array}{c}\text { \# Female Lead } \\
\text { Independent } \\
\text { Directors }\end{array}$ & $\begin{array}{c}\text { \% of Entire } \\
\text { Sample }\end{array}$ & $\begin{array}{c}\text { \% of Female } \\
\text { Directors }\end{array}$ & $\begin{array}{c}\text { \# Male Lead } \\
\text { Independent } \\
\text { Directors }\end{array}$ & $\begin{array}{c}\text { \% of } \\
\text { Entire } \\
\text { Sample }\end{array}$ & $\begin{array}{c}\text { \% of Male } \\
\text { Directors }\end{array}$ & $\begin{array}{c}\text { Total } \\
\text { Directors }\end{array}$ \\
\hline 2010 & 28 & $0.39 \%$ & $2.73 \%$ & 434 & $6.08 \%$ & $7.09 \%$ & 7143 \\
\hline 2011 & 39 & $0.50 \%$ & $3.38 \%$ & 492 & $6.33 \%$ & $7.43 \%$ & 7777 \\
\hline 2012 & 43 & $0.54 \%$ & $3.51 \%$ & 516 & $6.45 \%$ & $7.61 \%$ & 8002 \\
\hline 2013 & 44 & $0.52 \%$ & $3.30 \%$ & 521 & $6.21 \%$ & $7.39 \%$ & 8384 \\
\hline 2014 & 49 & $0.57 \%$ & $3.40 \%$ & 534 & $6.18 \%$ & $7.42 \%$ & 8639 \\
\hline
\end{tabular}

Some may argue that the gap in leadership roles may be explained by the fact that women have yet to achieve sufficient tenure, especially due to the increased addition of women to boards in recent years. Therefore, as their tenure increases in the next 5-10 years so would their leadership representation. The data contradicts this line of reasoning. First, as discussed above, the tenure gap is not merely a result of the

133. To prevent skewing of the results by the subset of chairs who are also CEOs (and are overwhelmingly men), the study only examined chair roles held by independent directors.

134. Similarly, according to a recent Equilar report, in 2016, only $7.6 \%$ of nonexecutive chair, CEO/Chair, or lead director roles were occupied by women. Boardroom Indicator: 18.9\%, EQUILAR (Oct. 27, 2016), https://www.equilar.com/blogs/bi/10-27-2016-boardroomindicator-18.9.html [https://perma.cc/5LRD-22CX].

135. See Krause et. al., supra note 132 ("[M] any have argued that the CEO and chair positions must be separated to prevent the conflict of interest inherent to the CEO leading the board."). 
addition of women in greater numbers. ${ }^{136}$ Second, when examining the leadership percentages of each gender, the gap is not a function of tenure. According to the results displayed in Table 5, the data shows consistent gaps in leadership likelihood even after controlling for tenure. In each of the four tenure quartiles, women lag men in their likelihood to take the role of chair or lead independent director.

\section{Table 5: Leadership Roles and Tenure}

\begin{tabular}{|c|c|c|c|c|c|c|c|c|}
\hline & \multicolumn{3}{|c|}{ Leadership Role Likelihood (as a percentage of the respective sample) } \\
\hline & $\begin{array}{r}\text { 0-4 Years of } \\
\text { Tenure }\end{array}$ & $\begin{array}{r}4-8 \text { Years of } \\
\text { Tenure }\end{array}$ & $\begin{array}{r}\text { 8-12 Years of } \\
\text { Tenure }\end{array}$ & \multicolumn{2}{c|}{$\begin{array}{c}12+\text { Years of } \\
\text { Tenure }\end{array}$} \\
\hline & Female & Male & Female & Male & Female & Male & Female & Male \\
\hline 2007 & $0.63 \%$ & $2.12 \%$ & $0.75 \%$ & $2.19 \%$ & $0.50 \%$ & $1.78 \%$ & $0.31 \%$ & $4.11 \%$ \\
\hline 2008 & $0.88 \%$ & $2.80 \%$ & $0.82 \%$ & $3.09 \%$ & $0.65 \%$ & $2.24 \%$ & $0.59 \%$ & $4.74 \%$ \\
\hline 2009 & $0.99 \%$ & $2.43 \%$ & $1.16 \%$ & $2.93 \%$ & $0.87 \%$ & $2.39 \%$ & $0.58 \%$ & $5.19 \%$ \\
\hline 2010 & $1.00 \%$ & $2.30 \%$ & $0.94 \%$ & $3.36 \%$ & $0.94 \%$ & $2.92 \%$ & $1.11 \%$ & $6.24 \%$ \\
\hline 2011 & $0.49 \%$ & $0.91 \%$ & $0.76 \%$ & $2.33 \%$ & $0.87 \%$ & $2.56 \%$ & $1.25 \%$ & $5.89 \%$ \\
\hline 2012 & $0.47 \%$ & $0.90 \%$ & $0.63 \%$ & $2.18 \%$ & $0.94 \%$ & $2.72 \%$ & $1.41 \%$ & $6.14 \%$ \\
\hline 2013 & $0.49 \%$ & $0.91 \%$ & $0.69 \%$ & $2.20 \%$ & $0.89 \%$ & $2.48 \%$ & $1.28 \%$ & $6.32 \%$ \\
\hline 2014 & $0.37 \%$ & $1.02 \%$ & $0.56 \%$ & $2.16 \%$ & $1.02 \%$ & $2.44 \%$ & $1.44 \%$ & $6.16 \%$ \\
\hline 2015 & $0.35 \%$ & $1.28 \%$ & $0.62 \%$ & $1.84 \%$ & $0.88 \%$ & $2.30 \%$ & $1.71 \%$ & $6.09 \%$ \\
\hline
\end{tabular}

\section{Service on Other Boards}

One of the criteria in looking for new directors is prior experience. ${ }^{137}$ With fewer women holding existing directorship experience, these women might be more likely to serve on multiple boards. In other words, with a smaller potential pool of candidates, boards may be tapping the same women to fill diversity initiatives, instead of expanding the pool altogether. The data presented in Figure 4 support this argument. The average number of boards on which female directors sit on has remained relatively constant throughout the time period starting at 1.97 boards in 2007 to 1.95 boards in 2015 . For men, however, the average number of boards has decreased from 1.88 to 1.78 over the same period.

136. See supra Section II.B.1.

137. Renée B. Adams, Ali C. Akyol \& Patrick Verwijmeren, Director Skill Sets 44 (Mar. 31, 2017) (unpublished manuscript), https://papers.ssrn.com/sol3/papers.cfm?abstract _id=2365748 [https://perma.cc/MD8C-VGR9] (finding that $13 \%$ of nominating committees specifically list outside board experience as a requisite qualification for inclusion as a nominee). 
Figure 4: Average Number of Boards Directors

Sit On by Gender and Year (2007-2015)

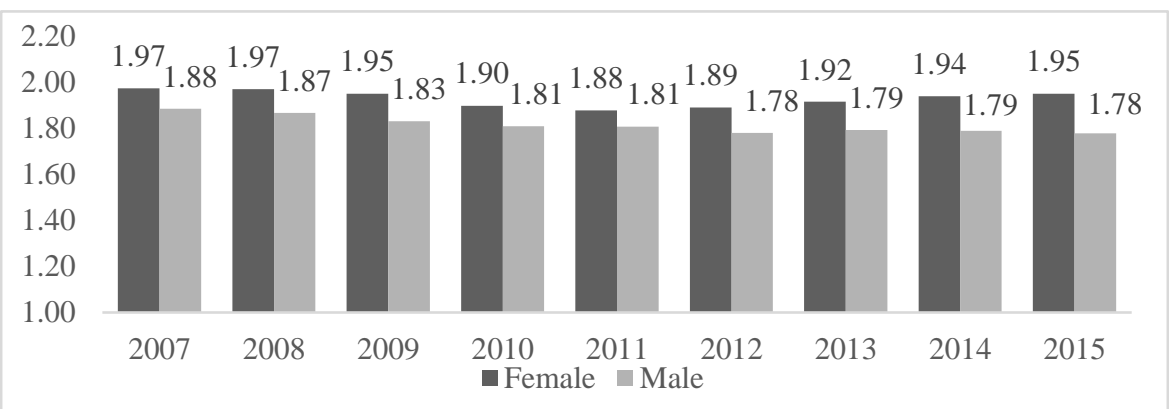

Table 6 breaks out this information by S\&P index. Looking across the indices, on average, the smaller cap stocks have fewer "busy" or "overboarded directors." 138 That is, both men and women are less likely to serve on multiple boards in smaller cap indices. Further, the gap between the number of boards each gender sits on shrinks when moving from the S\&P 500 to the S\&P 600. For example, in 2015 the difference in average number of boards between women and men in S\&P 500 companies was .15 boards whereas in the S\&P 600 the difference was only .06 boards.

Table 6: Average Number of Boards Directors

Sit On by Gender, Year, and Index (2007-2015)

\begin{tabular}{|l|l|l|l|l|l|}
\hline & & \multicolumn{1}{|c|}{2007} & \multicolumn{1}{|c|}{2010} & \multicolumn{1}{|c|}{2012} & \multicolumn{1}{|c|}{2015} \\
\hline \multirow{2}{*}{ S\&P 500 } & Female & 2.25 & 2.16 & 2.09 & 2.18 \\
\cline { 2 - 6 } & Male & 2.17 & 2.06 & 2.03 & 2.03 \\
\hline \multirow{2}{*}{ S\&P 400 } & Female & 1.82 & 1.76 & 1.87 & 1.93 \\
\cline { 2 - 6 } & Male & 1.87 & 1.77 & 1.75 & 1.75 \\
\hline \multirow{2}{*}{ S\&P 600 } & Female & 1.64 & 1.56 & 1.58 & 1.61 \\
\cline { 2 - 6 } & Male & 1.62 & 1.58 & 1.56 & 1.55 \\
\hline
\end{tabular}

\section{Service on Board Committees}

What roles do women and men hold on the various key committees ${ }^{139}$ in the boardroom? Examining the membership on specific board committees provides a

138. "Busy Directors" are characterized as individuals who serve on multiple boards. This term generally has a negative connotation in that busy directors spend so much time on different boards that they are unable to devote their full time to any given board. Evidence of directors after mergers suggests that busy directors are associated with worse corporate performance and lower earnings. See May Hu \& Pei Ni Huynh, How Do Cross-Border Mergers and Acquisitions Affect Firms' Management and Stakeholders? Part 2, 20 CORP. FIN. REV. 13, 21 (2015).

139. These are the Audit, Compensation, Corporate Governance, and Nominating committees. See supra notes 54-57 and accompanying text. 
more accurate picture of each director's role on the board and the impact they may have on the corporation. ${ }^{140}$ This substantive aspect can enable us to better detect whether women are equal partners on the board, whether women are relegated to a secondary role within the boardroom, or whether women take an increased workload due to their lower numbers.

\section{a. Average Number of Committees}

Throughout the entire sample period, women sat on between .25 (2009) and .20 (2014) more board committees than their male counterparts. This suggests that female directors have an increased workload on the board as compared to male directors.

Figure 5: Average Number of Committees per Board

Directors by Gender and Year (2007-2015)

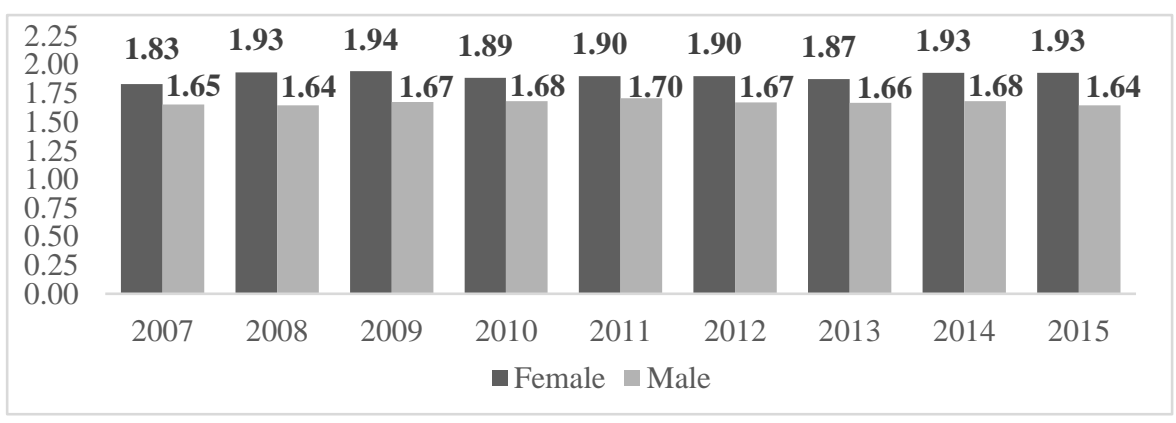

b. Percent of Men and Women on At Least One Board Committee

Because directors sitting on more than two board committees can skew the average number of committees higher, looking at the relative pools of directors who sit on more than one board can help confirm the conclusions of the previous Section. Figure 6 presents the data. In 2015, 84\% of women directors compared to $71 \%$ of men directors served on at least one committee. ${ }^{141}$ Thus, female directors outpace their male counterparts, both in terms of average committees and involvement on at least one committee.

140. See Klein, supra note 53.

141. This percentage point difference existed in three of the sample years where in the other six years the difference was fourteen percentage points. 
Figure 6: Percentage of Men and Women on At Least

One Committee by Year (2007-2015)

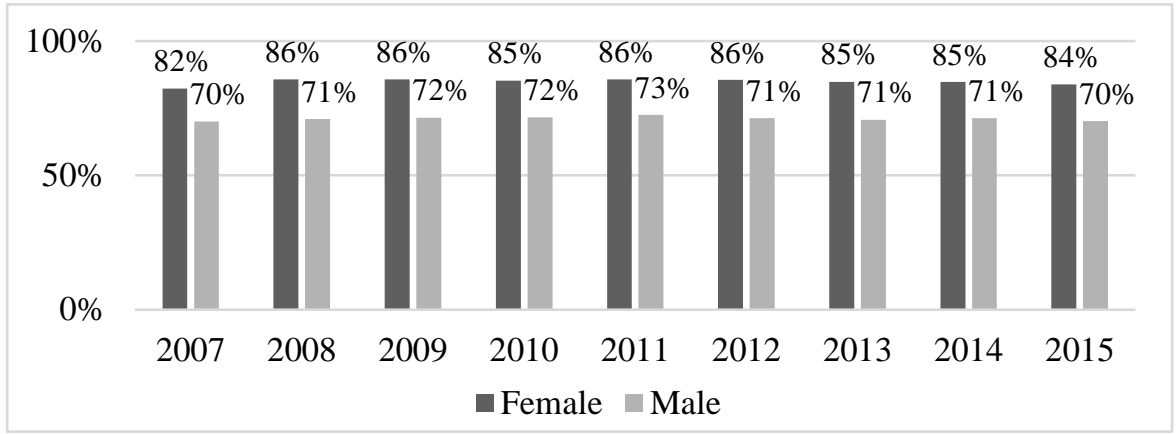

c. Likelihood of Sitting on a Given Number of Committees

Men are much more likely to participate on zero committees while women are more likely to participate on one, two, or three committees throughout the sample period. A woman had a $31 \%$ chance of sitting on three committees, $19 \%$ chance of sitting on two committees, and $29 \%$ chance of sitting on one committee. A man, on the other hand, had a $25 \%$ chance of sitting on three committees, $18 \%$ chance of sitting on two committees, and $23 \%$ chance of sitting on one committee. Accordingly, women directors seem to be tasked with more committee work than their male counterparts are. Table 8 breaks down the percentages of female board directors by industry and number of committees. ${ }^{142}$

142. Table 8 statistical results are from a univariate regression model used to break down the averages from Table 7 by industry. Unless otherwise noted, the average of each industry was statistically significantly different from the average of the rest of the sample at the 5\% level. The average likelihood for women to sit on zero committees was $13 \%$. Given a female that was in Consumer Services, that likelihood rose to $20.5 \%$, while for Industrial Services that likelihood declined to $10.4 \%$. The average likelihood for any given female director to sit on one committee was $30 \%$. If a given female was on Technology Services, that likelihood rose to $33.7 \%$, however for Consumer Services that likelihood declined to $22.6 \%$. The average likelihood of a female sitting on two committees across all industries was $20 \%$. If that female was on a Consumer Services board, the likelihood was $29.1 \%$ whereas an Industrial Services female board member had a $15.2 \%$ chance of being on two committees. Next, the average likelihood for a female to sit on three committees is $32 \%$. At the top end, if a female is on a Retail Trade board, the likelihood rises to $35.9 \%$ and on the low end a female on a Consumer Services board has a $25.3 \%$ chance of sitting on three committees. Finally, the likelihood for a female to sit on four committees is $5 \%$. Again, a female on a Consumer Services board only has a $2.6 \%$ chance of sitting on four committees while a female on an Industrial Services board has an $8 \%$ chance of the same. 
Table 7: Percent of Directors Participating on Multiple Committees by Number of Committees and Gender

\begin{tabular}{|l|l|l|l|l|l|}
\hline & \multicolumn{1}{|c|}{ Zero } & \multicolumn{1}{c|}{ One } & \multicolumn{1}{c|}{ Two } & \multicolumn{1}{c|}{ Three } & \multicolumn{1}{c|}{ Four } \\
\hline Female & $16 \%$ & $29 \%$ & $19 \%$ & $31 \%$ & $5 \%$ \\
\hline Male & $28 \%$ & $23 \%$ & $18 \%$ & $25 \%$ & $6 \%$ \\
\hline
\end{tabular}

Table 8: Percent of Female Board Directors Participating on Multiple Committees by Number of Committees and Industry

\begin{tabular}{|l|l|l|l|l|l|}
\hline \multicolumn{1}{|c|}{ Industry } & \multicolumn{1}{c|}{ Zero } & \multicolumn{1}{c|}{ One } & \multicolumn{1}{c|}{ Two } & \multicolumn{1}{c|}{ Three } & \multicolumn{1}{c|}{ Four } \\
\hline $\begin{array}{l}\text { Consumer } \\
\text { Services }\end{array}$ & $.205^{* * *}$ & $.226^{* * *}$ & $.291^{* * *}$ & $.253^{* * *}$ & $.026^{* * *}$ \\
\hline $\begin{array}{l}\text { Electronic } \\
\text { Technology }\end{array}$ & .129 & .315 & $.168^{* * *}$ & $.346^{*}$ & .042 \\
\hline Finance & $.155^{* * *}$ & $.320^{* * *}$ & $.174^{* * *}$ & $.281^{* * *}$ & $.069^{* * *}$ \\
\hline $\begin{array}{l}\text { Industrial } \\
\text { Services }\end{array}$ & .104 & .332 & $.152^{* *}$ & .332 & $.080^{* *}$ \\
\hline Retail Trade & $.155^{* *}$ & $.238^{* * *}$ & $.174^{* * *}$ & $.359^{* * *}$ & $.074^{* *}$ \\
\hline $\begin{array}{l}\text { Technology } \\
\text { Services }\end{array}$ & .124 & $.337^{* *}$ & .207 & .299 & $.033^{* *}$ \\
\hline Utilities & .111 & .302 & .224 & .325 & $.038^{*}$ \\
\hline Average & .13 & .3 & .2 & .32 & .05 \\
\hline $\begin{array}{l}\text { Difference } \\
\text { from Largest } \\
\text { to Smallest }\end{array}$ & .101 & .111 & .139 & .106 & .054 \\
\hline
\end{tabular}

Table 8: Statistical significance determined using univariate regression. $* * *(* *, *)$ indicates statistical significance at the $1 \%(5 \%, 10 \%)$ levels.

Next, the analysis examined the likelihood that an individual director sits on a specific number of board committees (ranging from zero to four). ${ }^{143}$ The regression results are presented in Table 9. For example, all coefficients for Female are positive, suggesting that being a female has a stronger influence on serving on one or more committees than it does on serving on zero committees. Being a female has the strongest effect for serving on three committees. The effect of age increases as we move from zero to four committees. Industry type also matters at times. For example, Industrial Services directors are more likely to serve on four committees than on zero committees. For other industries, directors are less likely to serve on more committees.

143. The process of estimating the likelihood took three steps. First, a multinomial logistic regression analysis was used to model the number of committees a board member participated on as a function of the director's gender, age, and the industry of company (a multinomial logistic regression is preferred when the dependent variable consists of multiple, related binary categories. Here the dependent variable is whether a director served on zero, one, two, three, or four committees). Next, a number of hypothetical scenarios were created. Finally, coefficients from the regression analysis were used to estimate the probability of a member serving on specified numbers of committees for each scenario. 
Table 9: Regression Results

\begin{tabular}{|c|c|c|c|c|}
\hline & $\begin{array}{c}\text { One } \\
\text { Committee }\end{array}$ & $\begin{array}{c}\text { Two } \\
\text { Committees }\end{array}$ & $\begin{array}{c}\text { Three } \\
\text { Committees }\end{array}$ & $\begin{array}{c}\text { Four } \\
\text { Committees }\end{array}$ \\
\hline Female & $0.951 * * *$ & $0.866 * * *$ & $1.027 * * *$ & $0.623^{* * *}$ \\
\hline Company Age & $0.033 * * *$ & $0.053 * * *$ & $0.059 * * *$ & $0.079 * * *$ \\
\hline Consumer Services (industry) & $-0.271 * *$ & $-0.255^{*}$ & $-0.403 * * *$ & $-0.985 * * *$ \\
\hline $\begin{array}{l}\text { Electronic Technology } \\
\text { (industry) }\end{array}$ & -0.077 & $-0.199 * *$ & -0.130 & -0.147 \\
\hline Finance (industry) & $-0.229 * * *$ & $-0.316 * * *$ & $-0.405 * * *$ & 0.002 \\
\hline Industrial Services (industry) & -0.263 & -0.209 & -0.231 & $0.521 * * *$ \\
\hline Retail Trade (industry) & $-0.205 *$ & $-0.489 * * *$ & $-0.289 * * *$ & 0.047 \\
\hline $\begin{array}{l}\text { Technology Services } \\
\text { (industry) }\end{array}$ & -0.011 & -0.157 & -0.181 & -0.054 \\
\hline Utilities (industry) & 0.180 & 0.050 & -0.065 & -0.245 \\
\hline Constant & $-2.176^{* * *}$ & $-3.664 * * *$ & $-3.726 * * *$ & $-6.634 * * *$ \\
\hline $\mathrm{N}$ & \multicolumn{4}{|l|}{12,432} \\
\hline AIC & \multicolumn{4}{|l|}{37135} \\
\hline
\end{tabular}

Table 9: This Table presents results from a multinomial logistical regression where the dependent variable is whether the director served on zero, one, two, three, or four committees. $* * *(* *, *)$ indicates statistical significance at the $1 \%(5 \%, 10 \%)$ levels. The zero committee category is the reference category, so coefficients are relative to their estimated influence on serving on zero committees.

\section{d. Likelihood of Sitting on a Given Committee}

One potential gender parity concern is that women may be excluded from specific important board committees. The descriptive statistics in Table 10 mostly alleviate such a concern as women are serving in large numbers on all of the key board committees. ${ }^{144}$

144. Unless otherwise indicated, the differences between industries were statistically significant at the $5 \%$ level. 
Table 10: Percent of Board Directors that Are Female in Each Industry of Each Committee Type

\begin{tabular}{|l|l|l|l|l|}
\hline \multicolumn{1}{|c|}{ Industry } & Nominating & $\begin{array}{c}\text { Corporate } \\
\text { Governance }\end{array}$ & Compensation & \multicolumn{1}{c|}{ Audit } \\
\hline Consumer Services & $.421 * * *$ & $.418 * * *$ & .448 & $.384 * * *$ \\
\hline Electronic Technology & .47 & .47 & .453 & .464 \\
\hline Finance & $.45 * * *$ & $.442 * * *$ & $.407 * * *$ & $.488^{* * *}$ \\
\hline Industrial Services & .477 & .477 & $.496 * *$ & $.501 *$ \\
\hline Retail Trade & .509 & .508 & $.472 * *$ & .468 \\
\hline Technology Services & .46 & .451 & .42 & .48 \\
\hline Utilities & .479 & .474 & .458 & .464 \\
\hline Average & .49 & .48 & .44 & .46 \\
\hline $\begin{array}{l}\text { Difference from Largest } \\
\text { to Smallest }\end{array}$ & .088 & .09 & .089 & .094 \\
\hline
\end{tabular}

Table 10: Statistical significance determined using univariate regression. *** $(* * *)$ indicates statistical significance at the $1 \%(5 \%, 10 \%)$ levels.

Following these descriptive statistics, the study modeled whether an individual is on each of the four committees using a logistic regression. ${ }^{145}$ The independent variables remain Age, Gender, and Industry. The results of the four logistic regressions are displayed in Table $11 .{ }^{146}$ Females are more likely than their male colleagues to serve on the Corporate Governance and Compensation committees and less likely than males to serve on the Audit Committee after controlling for Age and Industry. When it comes to serving on these specific committees, however, there is little variation by industry. The lone exception is that individuals in the Retail Trade industry are slightly less likely to serve on the Corporate Governance Committee than those in other industries. Older individuals are more likely to serve on the Corporate Governance Committee while younger individuals are less likely to serve on the Audit Committee.

145. A logistic regression is appropriate when the dependent variable is a single binary outcome.

146. The few individuals serving on nominating committees make the coefficient estimates for this regression highly uncertain. 
Table 11: Regression Results

\begin{tabular}{|l|l|l|l|l|}
\hline & $\begin{array}{c}\text { Nominating } \\
\text { Committee } \\
\text { Female }\end{array}$ & $\begin{array}{c}\text { Corporate } \\
\text { Governance } \\
\text { Committee }\end{array}$ & $\begin{array}{c}\text { Compensation } \\
\text { Committee }\end{array}$ & \multicolumn{1}{|c|}{$\begin{array}{c}\text { Audit } \\
\text { Committee }\end{array}$} \\
\hline Company Age & -1.037 & $0.254 * * *$ & $0.128 * *$ & $-0.214 * * *$ \\
\hline $\begin{array}{l}\text { Consumer } \\
\text { Services (industry) }\end{array}$ & -16.223 & $0.012 * * *$ & 0.004 & $-0.008^{* * *}$ \\
\hline $\begin{array}{l}\text { Electronic } \\
\text { Technology } \\
\text { (industry) }\end{array}$ & 0.102 & -0.077 & 0.039 & -0.091 \\
\hline Finance (industry) & 0.435 & 0.028 & -0.010 & 0.038 \\
\hline $\begin{array}{l}\text { Industrial Services } \\
\text { (industry) }\end{array}$ & -16.359 & -0.199 & -0.073 & 0.049 \\
\hline $\begin{array}{l}\text { Retail Trade } \\
\text { (industry) }\end{array}$ & -16.194 & $-0.284 *$ & -0.028 & 0.106 \\
\hline $\begin{array}{l}\text { Technology } \\
\text { Services (industry) }\end{array}$ & -16.197 & -0.039 & 0.000 & 0.107 \\
\hline Utilities (industry) & -16.263 & 0.168 & -0.019 & -0.046 \\
\hline Constant & $-8.857 * * *$ & $-2.939 * * *$ & $-0.938 * * *$ & $0.783 * * *$ \\
\hline N & 16 & 995 & 3049 & 5122 \\
\hline AIC & 243 & 6299 & 11685 & 12601 \\
\hline
\end{tabular}

Table 11: This Table presents results from four separate logistic regressions where the dependent variables are whether the director served on the Nominating, Corporate Governance, Compensation, or Audit Committees. $* * *(* *, *)$ indicates statistical significance at the $1 \%(5 \%, 10 \%)$ levels.

\section{e. Committee Chair Position}

As shown in Part II.B.4, board leadership positions tilt heavily in favor of male directors. Looking at leadership at the board committee level, the Article finds that female directors are also underrepresented in board committee leadership. Yet, there has been a steady improvement in female committee leadership over time. Table 12 below illustrates the improvement in the percentage of female committee chairs over time while also showing that the ratio of women chairs still lags behind their relative representation on these committees. For instance, while in 2007 only $7 \%$ of Audit Committee chairs in the sample were women (102 directors), that ratio doubled to $14 \%$ in 2015 (210 directors). However, in both years the percentage of Audit Committee members that were women was significantly higher compared to their committee chair representation. In 2007, $12 \%$ of the Audit Committee members were women while only $7 \%$ served as chairs, and in 2015, $18 \%$ of the Audit Committee members were women with only $14 \%$ serving as chairs. These disparities are statistically significant and hold across committees and over time. 
Table 12: Comparison of Committee Chair Position

\begin{tabular}{|c|l|l|l|l|l|}
\hline Year & $\begin{array}{c}\text { Nomination } \\
\text { Committee }\end{array}$ & $\begin{array}{c}\text { Governance } \\
\text { Committee }\end{array}$ & $\begin{array}{l}\text { Compensation } \\
\text { Committee }\end{array}$ & $\begin{array}{c}\text { Audit } \\
\text { Committee }\end{array}$ & $\begin{array}{c}\text { Any } \\
\text { Committee }\end{array}$ \\
\hline \multirow{2}{*}{2007} & $.12 / .13^{*}$ & $.12 / .14^{*}$ & $.08 / .12^{*}$ & $.07 / .12^{*}$ & $.11 / .13^{*}$ \\
& $(164 / 737)$ & $(162 / 734)$ & $(120 / 658)$ & $(102 / 698)$ & $(446 / 1342)$ \\
\hline \multirow{2}{*}{2008} & $.12 / .14^{*}$ & $.12 / .14^{*}$ & $.10 / .12^{*}$ & $.08 / .13^{*}$ & $.11 / .14^{*}$ \\
& $(171 / 814)$ & $(167 / 812)$ & $(139 / 708)$ & $(118 / 739)$ & $(477 / 1456)$ \\
\hline \multirow{2}{*}{2009} & $.12 / .14^{*}$ & $.12 / .14^{*}$ & $.09 / .13^{*}$ & $.09 / .13^{*}$ & $.11 / .14^{*}$ \\
& $(173 / 823)$ & $(170 / 822)$ & $(138 / 740)$ & $(134 / 753)$ & $(481 / 1481)$ \\
\hline \multirow{2}{*}{2010} & $.13 / .14^{*}$ & $.13 / .14^{*}$ & $.10 / .13^{*}$ & $.10 / .13^{*}$ & $.12 / .14^{*}$ \\
& $(183 / 839)$ & $(179 / 832)$ & $(151 / 772)$ & $(142 / 769)$ & $(513 / 1531)$ \\
\hline \multirow{2}{*}{2011} & $.14 / .15^{*}$ & $.14 / .15^{*}$ & $.10 / .13^{*}$ & $.10 / .14^{*}$ & $.13 / .14^{*}$ \\
& $(197 / 852)$ & $(195 / 850)$ & $(153 / 753)$ & $(154 / 800)$ & $(545 / 1552)$ \\
\hline \multirow{2}{*}{2012} & $.13 / .15^{*}$ & $.13 / .16^{*}$ & $.11 / .14^{*}$ & $.12 / .14^{*}$ & $.13 / .15^{*}$ \\
& $(197 / 891)$ & $(195 / 885)$ & $(165 / 806)$ & $(174 / 852)$ & $(557 / 1655)$ \\
\hline \multirow{2}{*}{2013} & $.15 / .16^{*}$ & $.15 / .16^{*}$ & $.12 / .15^{*}$ & $.12 / .15^{*}$ & $.14 / .16^{*}$ \\
& $(225 / 949)$ & $(224 / 945)$ & $(175 / 855)$ & $(187 / 929)$ & $(624 / 1764)$ \\
\hline \multirow{2}{*}{2014} & $.16 / .17$ & $.16 / .17$ & $.13 / .16^{*}$ & $.14 / .17^{*}$ & $.15 / .17^{*}$ \\
& $(235 / 1002)$ & $(236 / 994)$ & $(187 / 924)$ & $(211 / 968)$ & $(658 / 1855)$ \\
\hline \multirow{2}{*}{2015} & $.16 / .19^{*}$ & $.16 / .19^{*}$ & $.14 / .17^{*}$ & $.14 / .18^{*}$ & $.15 / .18^{*}$ \\
& $(241 / 1070)$ & $(239 / 1063)$ & $(204 / 973)$ & $(210 / 1030)$ & $(684 / 1964)$ \\
\hline
\end{tabular}

Table 12: This Table presents the percentage of female committee chairs compared to their ratio on the committee. The first number in each cell is the proportion of companies with a female chair on a given committee and year. The second number is the average proportion of female directors on a given committee and year for all companies in the data. The star indicates that the second number in a cell is statistically distinguishable from the first. The first number in the parentheses is the raw number of female chairs and the second number is the raw number of female directors on these committees.

\section{Key Lessons from the Findings}

Several broad observations can be drawn from the empirical findings. First, it is clear that important differences exist between genders not only in the quantitative numbers of each gender in the boardroom but also in the substantive characteristics and roles within the boardroom that each gender is more likely to hold.

Second, the data show that differences between genders vary both across different industries and across market cap sizes. These differences highlight the need to examine companies on an individual level, rather than through an aggregate ratio, for a true and more complete assessment of the gender parity on boards. The variation the data show is also important for future academic research. As discussed above, a large body of empirical literature is focused on the link between gender diversity and company performance. ${ }^{147}$ These studies have yet to use data on substantive diversity, such as the data presented in this Article. Combining this new data with the quantitative data analyzed in prior studies can better reveal gradations between female participation in the boardrooms and the impact on company performance.

147. See supra Section I.C. 
Third, the data on substantive diversity are full of nuance and are subject to interpretation. While some of the results may more clearly suggest a concern regarding gender parity, other findings are less clear-cut, and some of the findings provide a more optimistic depiction of substantive parity.

Finally, it is important to underscore that the findings are limited to available data regarding director participation in the boardroom. The aforementioned variables are, of course, not an exhaustive list, and they do not reflect less observable data such as board dynamics and other measures of clout that are important factors for a more complete picture of the gender parity in each boardroom.

Moving to some of the specific findings, several trends suggest a potential lack of substantive gender parity. First, the shorter tenure of women on boards should be of potential concern. Tenure has been recognized to play an important role in the influence that one possesses. ${ }^{148}$ Since longer tenured directors arguably carry more clout and influence in the board room, ${ }^{149}$ they might inhibit and restrain, intentionally or inadvertently, the ability and willingness of less tenured directors to act independently and might jeopardize the ability of the boardroom to foster an "open to all ideas" atmosphere. ${ }^{150}$ If there is a significant tenure disparity along gender lines, as the findings suggest, then women might face an uphill battle to have their voice heard in a boardroom controlled by long-tenured male directors. ${ }^{151}$ The fact that women are already a minority in the boardroom further magnifies the impact of tenure disparity. Studies have found that without a critical mass ${ }^{152}$ women encounter "social isolation . . . heightened visibility" and pressure to accept "stereotyped roles." 153 Tenure disparity may exacerbate these concerns, making women even less likely to overcome these obstacles.

Importantly, the Article finds that director tenure is positively correlated with the likelihood of having a leadership role. ${ }^{154}$ If women systematically serve for shorter terms, then their opportunities to take these leadership roles is negatively affected. Clearly, the tenure disparity is concerning as it may influence the intraboard dynamics. It is also important to understand why women leave boards faster than men. Are they pushed out (explicitly or implicitly)? Do they suffer from

148. Cf. Einer Elhauge, Are Term Limits Undemocratic?, 64 U. CHI. L. REV. 83, 125 (1997) (describing the impact tenure has on power, clout, and influence in the political sphere).

149. See Nili, supra note 52 (discussing the impact of director tenure on the board dynamics).

150. Id.

151. Of course, in some instances, long-tenured directors are less involved in the boardroom work, or newer directors exert more influence than their longer termed peers do. However, generally tenure correlates with greater clout.

152. Rhode \& Packel, supra note 82, at 408-11 (discussing the issues with token directors and reviewing the studies finding that a critical mass is needed).

153. See Rosabeth Moss Kanter, The Problems of ToKenism 39-40 (1974) (monograph prepared for the Center for Research on Women in Higher Education and the Professions); see also Joan MacLeod Heminway \& Sarah White, Wanted: Female Corporate Directors, 29 PACE L. REV. 249, 257-64 (2009) (exploring behavior of token women directors on all-male boards).

154. The Article finds that leadership is positively correlated with a 1.51 years increase for males and a 0.62 years increase for females. Females in leadership roles have 1.96 fewer years of service than males (for nonleaders; females serve 2.85 fewer years among leaders). 
overextension and overcommitment to board committees? Or do they have more options to choose from, resulting in more frequent moves between boards?

Second, the underrepresentation of women in leadership roles, as chairwomen, as lead independent directors, or as committee chairs, is a potential signal regarding the level of substantive parity on the board. Women are less likely to hold leadership roles either as chair of the board/lead independent director or as chairs of the various board committees. These formal leadership roles carry significant formal powers. As chair, the director has control of the board or committee's agenda in addition to other formal and informal powers. In addition, these formal leadership roles carry a symbolic value, signaling the importance and value of the director. The fact that women do not hold these leadership positions in equal numbers, even relative to their current low ratio on the board, is a potential indication that they have yet to climb sufficiently high on the board's totem pole.

Third, the data reflect that the pool of female directors serving on public boards is smaller than the pool of males and that women serve on more than one board in greater numbers. The data also show that women are also more likely to serve on more board committees on each board. The smaller pool of women directors may reflect entry barriers to joining a board. It may be the case that some women are not considered for board positions due to nomination metrics that may overemphasize requisite work experience, positions that men are currently holding in much greater numbers. ${ }^{155}$ At the same time, the data indicate that women might be taking on more board work compared to their fellow directors. While this can stem from an attempt to ensure diversity in the many board committees, it may also lead to women to being overworked.

On the other side, the fact that women sit on multiple boards in greater numbers and the fact that they serve, on average, on more committees, can also be viewed in a positive light. Women enjoy greater exposure to the company (or different companies), which potentially allows them to enrich the board discussions and increase their clout within the board.

The data reflect better parity between the genders, or at least movement in the right direction, in some of the other metrics examined as well. The ratio of women on boards is on the rise. There has also been a positive movement in the ratio of women as committee chairs, signaling an overall positive trend. Finally, women seem to gain access to all of the important board committees, albeit in lesser numbers on the key audit committee.

In sum, the data exemplify the importance of a more detailed examination of the roles of women on boards. Women are clearly gaining ground in their representation on boards, but at the same time, significant disparities still exist between the genders regarding the roles and attributes of directors.

\section{THE REGULATORY FRAMEWORK AND ITS CURRENT FLAWS}

This Part reviews the current regulatory approach to gender diversity in boardrooms in the United States. In Section A, the Article describes the development

155. See Rhode \& Packel, supra note 82, at 404 (discussing the bias that might lead to underrepresentation of women on boards). 
of the current disclosure regime in the United States. Section B provides novel data on the gender diversity disclosure practices of companies, against the backdrop of the current regulatory framework. Section $\mathrm{C}$ then brings the two previous Sections together, underscoring the flaws in the current regulatory approach.

\section{A. The Evolution of Diversity Disclosure Requirements}

The United States has taken a soft regulatory approach ${ }^{156}$ to the issue of gender diversity, requiring companies to disclose only whether they have a diversity policy in place, ${ }^{157}$ and to provide a description of the policy to investors. ${ }^{158}$ This approach stands in sharp contrast to the mandatory diversity quotas many European countries have recently adopted, requiring companies to maintain a specific ratio of women to men on the board. ${ }^{159}$

Prior to 2009, boards in the United States were not required to make any disclosures regarding the nominating procedures related to diversity. ${ }^{160}$ In fact, Item 407 at the time made no mention at all of diversity. ${ }^{161}$

In its announcement of a 2009 amendment to Regulation S-K, the SEC noted it received numerous comments regarding the need for diversity disclosure within boards. ${ }^{162}$ Among the main advocates were two of the largest, and most socially active, pension funds: California Public Employees' Retirement System ("CalPERS") and California State Teachers' Retirement System ("CalSTRS"). ${ }^{163}$ The announcement noted that many of these commenters desired disclosure of diversity to provide insight into corporate governance practices. ${ }^{164}$ This, in turn, would provide additional information during proxy season when determining whether to vote for or against board nominees. ${ }^{165}$

In response to these communications, the SEC adopted Item 407(c) "requir[ing] disclosure of whether, and if so how, a nominating committee considers diversity in identifying nominees for director." 166 The regulation then requires that "if the nominating committee (or the board) has a policy with regard to the consideration of diversity in identifying director nominees, disclosure would be required of how this policy is implemented, as well as how the nominating committee (or the board) assesses the effectiveness of its policy." 167 The regulation, however, does not define

156. See DHIR, supra note 20, at 82 .

157. See SEC Corporate Governance, 17 C.F.R. $§ 229.407$ (2018).

158. Id.

159. See Véronique Magnier \& Darren Rosenblum, Quotas and the Transatlantic Divergence of Corporate Governance, 34 Nw. J. INT'L L. \& Bus. 249 (2014).

160. See Rhode \& Packel, supra note 82, at 418-19 (discussing the new requirements that were added in 2010).

161. See SEC Corporate Governance, 17 C.F.R. § 229.407 (2018).

162. Proxy Disclosure Enhancements, Exchange Act Release No. 33-9089, 74 Fed. Reg. 68334,68343 (Dec. 23, 2009) (to be codified at 17 C.F.R. $\S \S 229,239,249,274$ ).

163. Id. at 68343 n. 116.

164. Id. at $68344-45$.

165. Id. at 68334 .

166. Id. at 68343 .

167. Id. at $68343-44$. 
the term "diversity," and it left it to companies to define what they mean by diversity in their policies and disclosures. ${ }^{168}$

\section{B. Current Company Disclosures}

The regulatory framework, laid out in Section A, leaves a broad spectrum of parameters that constitute compliance with the SEC's diversity disclosure requirements, including making no diversity disclosure at all. Not surprisingly, companies vary in their board diversity disclosure practices. ${ }^{169}$ Some companies provide detailed information to investors regarding their diversity policies. ${ }^{170}$ Other companies merely recite the words necessary to comply with Item 407(c)(vi) and no more. $^{171}$

This Section explores director diversity disclosures in practice. To do so, using a hand-collected data set, the disclosure statements of one hundred public companies for the years of 2008, 2012, and 2016 were analyzed. ${ }^{172}$ To account for both large, high profile, companies as well as smaller, less visible public companies, fifty of the companies make up the Fortune 50 and the remaining fifty are Fortune 2000 smallcap companies. Some companies did not have proxy statements available in all of the three examined years, bringing the sample to ninety-four companies in 2008 and ninety-eight companies in 2012 and 2016, respectively.

As Figure 7 below shows, in 2008, only fifty-five of ninety-four companies disclosed that they considered diversity, in a general sense, at all. In 2012 and 2016, following the amendment to Regulation S-K, ${ }^{173}$ those numbers increased to ninetythree and ninety-five companies, respectively. However, corporations' consideration of diversity did not necessarily specifically include gender as part of the criteria for

168. Id. at 68344 .

169. See DHIR, supra note 20, at 173-213; Thomas Lee Hazen \& Lissa Lamkin Broome, Board Diversity and Proxy Disclosure, 37 U. DAYTOn L. Rev. 39, 59-66 (2011) (reviewing filings for 2010 for the Fortune 100 companies); Packel, supra note 85, at 223-28; Tamara S. Smallman, Note, The Glass Boardroom: The SEC's Role in Cracking the Door Open So Women May Enter, 2013 Colum. Bus. L. REv. 801, 817 (2013) (concluding that disclosures were "largely superficial and uninformative ... [and] failed to comply with the SEC's current regulation"). Dhir has conducted a similar survey of company disclosures for the years 2010 2013. DHIR, supra note 20 at 173-213. While our findings are similar in some aspects, we focus on different aspects of the disclosures, in addition to differences in the sample of companies and years covered.

170. See, e.g., Conn. Water Serv. Corp., Proxy Statement (Form DEF 14A) (Mar. 30, 2016); Essendant Inc., Proxy Statement (Form DEF 14A) (Apr. 13, 2016); Microsoft Corp., Proxy Statement (Form DEF 14A) (Oct. 18, 2016); Navient Corp., Proxy Statement (Form DEF 14A) (Apr. 15, 2016).

171. See, e.g., Discovery Comm., Inc., Proxy Statement (Form DEF 14A) (Mar. 30, 2016); Six Flags Entm't Corp., Proxy Statement (Form DEF 14A) (Mar. 22, 2016); Skechers U.S.A., Inc., Proxy Statement (Form DEF 14A) (Apr. 29, 2016).

172. The data was derived manually from a sample of 100 companies. This sample contains fifty Fortune 50 companies and fifty Fortune 2000 small-cap companies. For each company, the company's proxy statements in the years 2008, 2012, and 2016 were analyzed and coded. The complete data file is on file with the author.

173. See supra Section III.A. 
creating a more diverse board. In 2008, for instance, only five corporations specifically disclosed in their proxy statements that they consider gender as criteria for selecting director nominees. Although this number significantly increased to forty-two in 2012 and fifty-three in 2016, still only barely a majority of corporations indicated that they specifically considered gender when selecting director nominees.

\section{Figure 7: Trends in Gender Diversity Disclosure}

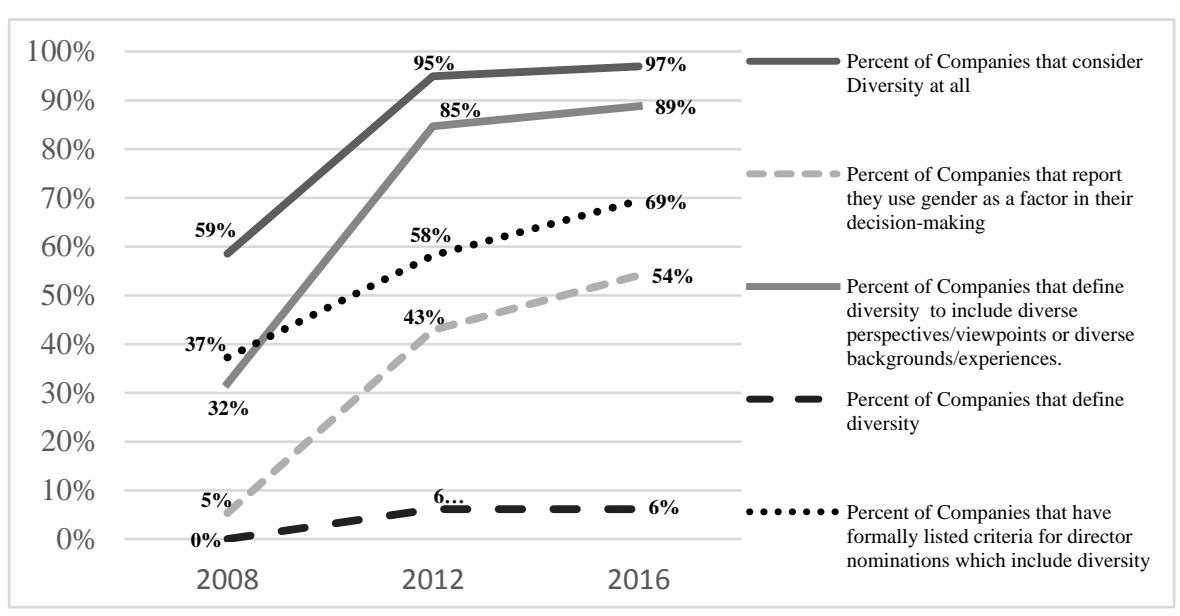

Importantly, many of the companies that do not have a formal policy in place have noted that while they lack a formal diversity policy, they consider the diversity of perspectives, experiences, and backgrounds of director nominees when slating a new board. For example, Quanex (NYSE: NX) uses the language, "[a]lthough the company has no formal policy on diversity for board members, the board considers diversity of experience and background in an effort to ensure that the composition of our directors creates a strong and effective board." ${ }^{174}$ While such language is compliant with the SEC rule, it illustrates the vagueness that companies can use when addressing diversity. ${ }^{175}$

Quanex is not an outlier. Only six out of the 100 companies reviewed currently have a definition of diversity laid out in their disclosures. Thus, even though

174. Quanex Bldg. Prods. Corp., Proxy Statement (Form DEF 14A) 69 (Jan. 29, 2016).

175. Contrast this approach with General Motors's (GM) statement:

Although GM does not have a formal policy governing diversity among Board members, we continually strive to add directors of diverse backgrounds. We recognize the value of overall diversity and consider members' opinions, perspectives, personal and professional experiences, and backgrounds, including gender, race, ethnicity, and country of origin, when considering Board candidates. We believe that the judgment and perspectives offered by a diverse board of directors improves the quality of decision-making and enhances the Company's business performance. We also believe such diversity can help the Board respond more effectively to the needs of customers, shareholders, employees, suppliers, and other stakeholders worldwide.

General Motors Co., Proxy Statement (Form DEF 14A) 10 (Apr. 22, 2016). 
corporations may have diversity policies, and at times they may explicitly seek gender diversity, an overwhelming majority of such policies lack the desired clarity and focus, instead crafted in a manner that dilutes any specific diversity criteria.

Concerns regarding the ability of current disclosure to truly promote gender diversity can be illustrated through the case of Emcor (NYSE: EME). In 2008, not unlike many of the other corporations in the study, Emcor had no reference to diversity in its disclosure, nor any women on its board. ${ }^{176}$ All eight directors on Emcor's board were men. ${ }^{177}$ More striking, however, was that both in 2012 and 2016 Emcor disclosed under the SEC requirements that it considers diversity in its nomination process but indicated that its focus is on obtaining a diversity of professional expertise rather than a diversity of personal characteristics. ${ }^{178}$ Not surprisingly, Emcor failed to add any women to the board even while increasing the total board size to ten directors. ${ }^{179}$

On the other hand, there are examples of companies that have made meaningful changes to their nomination process as well as to their boardroom diversity disclosure practices. One such example is Children's Place (NSDQ: PLCE). Although female directors in 2008 and 2012 only composed thirteen percent of Children's Place's board, ${ }^{180}$ the percentage of the board held by female directors jumped to thirty-six percent in 2016. ${ }^{181}$ These increases correlated with substantive changes in the corporation's policy towards board refreshment and diversity. In 2010, after the SEC regulation took effect, Children's Place added a consideration of gender as criteria when nominating directors. ${ }^{182}$ The company continued to improve its diversity policies and, in 2016, provided a clear graphic to investors detailing the gender composition of its board of directors. ${ }^{183}$ Further, Children's Place specifically stated that it seeks a board that has "an appropriate balance in terms of gender. Four of our Board members are women." ${ }^{84}$ This combination of clear visual information with an explicit and measurable policy provides a blueprint for effective and tangible gender diversity policies and disclosure practices.

More broadly, SEC disclosures reflect company policies that may be leading to concrete outcomes when it comes to a company's gender diversity. Indeed, the connection between what a company discloses to investors and its gender diversity ratio is not merely anecdotal. Examining the correlation between company disclosures and the ratio of women on the board, this Article found a statistically significant positive correlation. Specifically, as Table 13 below illustrates, companies that specifically addressed gender in their diversity disclosure were also

176. Emcor Group, Inc., Proxy Statement (Form DEF 14A) (Apr. 28, 2008).

177. See id.

178. See Emcor Group, Inc., Proxy Statement (Form DEF 14A) (Apr. 18, 2012); Emcor Group, Inc., Proxy Statement (Form DEF 14A) (Apr. 20, 2016).

179. See Emcor Group, Inc., Proxy Statement (Form DEF 14A) (Apr. 20, 2016).

180. See Children's Place, Inc., Proxy Statement (Form DEF 14A) (May 20, 2008); Children's Place, Inc., Proxy Statement (Form DEF 14A) (Apr. 24, 2012).

181. See Children's Place, Inc., Proxy Statement (Form DEF 14A) (Apr. 6, 2016).

182. See Children's Place, Inc., Proxy Statement (Form DEF 14A) (May 18, 2010).

183. See Children's Place, Inc., Proxy Statement (Form DEF 14A) (Apr. 6, 2016).

184. Id. at 9 . 
more likely to have higher ratio of females on their board, ${ }^{185}$ compared to companies without a diversity policy or one that solely refers to difference in viewpoints.

Table 13: Regression Results

\begin{tabular}{|l|l|l|}
\hline \multicolumn{1}{|c|}{ Type of Disclosure } & Year & $\begin{array}{c}\text { Percentage of Female } \\
\text { Directors } \\
\text { (correlation coefficient } \\
\text { (p-value) })\end{array}$ \\
\hline Consider diversity at all & 2008 & $0.213(0.038)$ \\
\hline Consider diversity at all & 2012 & $-0.070(0.489)$ \\
\hline Consider diversity at all & 2016 & $-0.031(0.756)$ \\
\hline Use gender as a factor in their decision-making & 2008 & $0.043(0.677)$ \\
\hline $\begin{array}{l}\text { Use gender as a factor in their decision-making } \\
\text { Use gender as a factor in their decision-making }\end{array}$ & 2012 & $0.286(0.004)$ \\
\hline $\begin{array}{l}\text { Define diversity to include diverse } \\
\text { perspectives/viewpoints }\end{array}$ & 2016 & $0.352(0.0003)$ \\
\hline $\begin{array}{l}\text { Define diversity to include diverse } \\
\text { perspectives/viewpoints }\end{array}$ & 2008 & $0.230(0.025)$ \\
\hline $\begin{array}{l}\text { Define diversity to include diverse } \\
\text { perspectives/viewpoints }\end{array}$ & 2012 & $-0.05596334(0.5842)$ \\
\hline
\end{tabular}

In sum, although the current state of diversity disclosures is reflective of the "soft" regulatory approach, it also exemplifies the value of meaningful disclosure to investors and the potential that a potent disclosure regime can provide.

\section{The Flaws with Current Disclosures}

The current regulatory approach, if truly intended to promote better gender diversity disclosure, suffers from several flaws. ${ }^{186}$ First, as others have noted, under the current rules diversity is an open-ended concept. ${ }^{187}$ Boards can include anything from gender and race to age and life experiences in defining diversity. ${ }^{188}$ In turn, many companies comply with the letter of the regulation by defining diversity broadly enough to incorporate any possible difference between people. ${ }^{189}$

185. Note that while the study found a correlation, it does not assert that there is a causation. In other words, companies may be willing to disclose that they consider gender because they have more women on the board.

186. The current regulatory approach has been criticized by several academics along similar lines. See, e.g., DHIR, supra note 20, at 71-94; Fairfax, Same Old Story, supra note 88, at 874-75; Rhode \& Packel, supra note 82, at 419.

187. See supra note 186.

188. Proxy Disclosure Enhancements, supra note 162, at 68343-44.

189. See, e.g., Discovery Comm., Inc., Proxy Statement (Form DEF 14A) (Mar. 30, 2016); Six Flags Entm't Corp., Proxy Statement (Form DEF 14A) (Mar. 22, 2016); Skechers U.S.A., Inc., Proxy Statement (Form DEF 14A) (Apr. 29, 2016); UnitedHealth Grp. Inc., Proxy 
Second, one of the major flaws of Regulation S-K noted by critics of the SEC approach is that it only applies to boards who have diversity policies in place but does not affirmatively require anything on behalf of boards without such policies. ${ }^{190}$ It has been suggested that one unintended consequence of this lack of an affirmative policy is to disincentivize companies from creating a diversity policy. ${ }^{191} \mathrm{~A}$ company that creates a diversity policy must not only explain how the policy is enacted and its results but also must describe how the policy works in practice. ${ }^{192}$ While some may argue that investors would nonetheless pressure companies into creating a policy, until recently that has not been the case. Instead of increasing disclosure and transparency, Regulation S-K has ironically restricted a company's incentive to draft diversity policies and increase the gender diversity of its board.

Third, beyond these effectively voluntary disclosures, the SEC requires no additional information with respect to boardroom gender diversity. ${ }^{193}$ This seems inconsistent with the intention of Item 407(c) as explicitly stated by the SEC. ${ }^{194}$ Investors expressed desire for information regarding diversity, ${ }^{195}$ yet a company can easily obscure its views on diversity. Thus, the requirements under Regulation S-K and the information provided by companies fail to adequately disclose the desired information.

When amending Regulation S-K in 2009, the SEC could have also included requirements for diversity in Item $407(\mathrm{c})(2)(\mathrm{v})$, which requires the company to:

Describe any specific minimum qualifications that the nominating committee believes must be met by a nominating committeerecommended nominee for a position on the registrant's board of directors, and describe any specific qualities or skills that the nominating committee believes are necessary for one or more of the registrant's directors to possess. ${ }^{196}$

However, not only did the SEC not add diversity to Item 407(c)(2)(v), but the SEC also explicitly excluded this Section from the diversity requirement ${ }^{197}$ and, in fact, included the diversity requirement directly after this Section. ${ }^{198}$ By specifically stating that the above requirement did not apply to diversity, companies without strong diversity policies have lacked an incentive to create one.

Statement (Form DEF 14A) (Apr. 22, 2016).

190. See DHIR, supra note 20, at 71-94; Fairfax, Same Old Story, supra note 88, at 87475; Rhode \& Packel, supra note 82, at 419.

191. See DHIR, supra note 20, at 251; Fairfax, Same Old Story, supra note 88, at 874-75.

192. See SEC Corporate Governance, 17 C.F.R. $\$ 229.407$ (c)(2)(vi) (2018).

193. See 17 C.F.R. § 229.407.

194. Disclosure Regarding Nominating Committee Functions and Communicating Between Security Holders and Board of Directors Republication, Exchange Act Release Nos. 33-8340, 34-48825, 68 Fed. Reg. 69204, 69210-13 (Dec. 11, 2003) (to be codified at 17 C.F.R. $\S \S 228,229,240,249,270,274)$.

195. Proxy Disclosure Enhancements, supra note 162, at 68343-44.

196. SEC Corporate Governance, 17 C.F.R. $\$ 229.407$ (c)(2)(vi) (2009).

197. See 17 C.F.R. $\$ 229.407$ (c)(2)(vi).

198. See id. 
In 2016, then SEC Chairwoman Mary Jo White described the role of the SEC in gender diversity, ${ }^{199}$ within the traditional focus of the SEC on disclosure, ${ }^{200}$ stating that "boards with diverse members function better and are correlated with better company performance[, which] is precisely why investors have - and should havean interest in diversity disclosure about board members and nominees." ${ }^{201}$ However, as she has noted ${ }^{202}$ and as this Article demonstrates, ${ }^{203}$ company policies remain vague. Further, very few companies have produced formal diversity policies, making it hard to evaluate the effectiveness of diversity policies. ${ }^{204}$ While Chairwoman White noted that the SEC had researched and prepared a recommendation to require companies to include in their proxy statements more meaningful board diversity disclosures on their board members and nominees ${ }^{205}$ no rule was ever formally announced and the often-criticized Item 407(c)(2)(vi) remains investors' only regulatory means of ascertaining diversity information in the boardroom.

This regulatory failure has led investors such as State Street and BlackRock to create comply-or-explain policies regarding gender diversity on the board, which are tied to their votes for board elections. ${ }^{206}$ In essence, these investors have effectively initiated a gender diversity "threshold" for companies to meet in order to avoid investor backlash. ${ }^{207}$ With the threat of upsetting these investors and opening the gates for activist shareholders to court these votes, companies are likely to meet the minimum requirements to comply with State Street and BlackRock's demands.

$$
* * * *
$$

The SEC's amendment in 2009 was a move in the right direction. At a minimum, it provided some information to investors regarding public companies' diversity policies and - as the data in Section B shows - it has clearly increased the number of companies that disclosed their diversity policies. It may have also influenced some companies to create diversity policies, which were previously absent, and it has

199. Mary Jo White, Focusing the Lens of Disclosure on Board Diversity, Non-GAAP, and Sustainability, Harv. L. SCh. F. CorP. Governance \& Fin. Reg. (June 28, 2016), https://corpgov.law.harvard.edu/2016/06/28/focusing-the-lens-of-disclosure-on-boarddiversity-non-gaap-and-sustainability [https://perma.cc/4ZV8-9PSG].

200. Id.

201. Id.

202. Id.

203. See supra Section III.B.

204. White, supra note 199.

205. Id.

206. Sharo M. Atmeh, State Street Global Advisors Announces New Gender Diversity Guidance, Harv. L. SCH. F. CoRP. GovernanCE \& FIN. REG. (Mar. 9, 2017), https://corpgov .law.harvard.edu/2017/03/09/state-street-global-advisors-announces-new-gender-diversity -guidance [https://perma.cc/AE6Y-772Z]; Scott Mlyn, BlackRock Vows New Pressure on Climate, Board Diversity, CNBC (Mar. 13, 2017, 3:48 AM), https://www.cnbc.com/2017/03 /13/blackrock-vows-new-pressure-on-climate-board-diversity.html [https://perma.cc/W857 $-5 \mathrm{~V} 7 \mathrm{~W}]$.

207. See Atmeh, supra note 206; Mlyn, supra note 206. Granted, in many cases these investors have left the door open for companies to rebuff this presumption through engagement. 
directed attention to the issue of gender diversity. However, the flaws in the current framework provide clear areas for potential reform that could make company disclosures even more effective and valuable. In the next Part, the Article discusses these potential reforms as part of a broader discussion of the policy implications stemming from the Article's findings regarding substantive gender diversity.

\section{POLICY IMPLICATIONS}

In Part II, the Article presented data on the composition and roles female directors hold on S\&P 1500 boards. The data show that differences between genders are reflected not only in the ratio of women to men but also in their roles once elected to the board. Furthermore, as with all averages, some companies perform better or worse than average in gender parity-potentially leading to cases where the quantitative parity of the board is not indicative of the substantive parity.

In other words, a company may have a higher than average number of women on the board but may relegate them to less important positions on the board while another company may have a lower number of women who are in key leadership positions on the board. While this might seem an unlikely scenario, similar issues exist in countries with mandated quotas. ${ }^{208}$

Furthermore, the composition of a company's board is fluid. In any given year, a company may lose or add a female director, therefore temporarily changing its gender ratio. It does not mean, however, that such company changed (for better or for worse) the level of substantive parity in its boardroom. These findings demonstrate that substantive diversity is important, and that attention needs to be paid to the differences in substantive diversity between men and women on boards.

Part III then examined the current SEC disclosure regime with respect to gender diversity on boards. The Article demonstrated that companies provide very little diversity information to their investors and discussed the current flaws in the disclosure regime.

This Part aims to bring together these two strands - the importance of substantive gender diversity and the deficiencies in the current disclosure regime - by discussing the policy implications of these findings. First, regulators, investors, and companies themselves should direct their attention to the question of substantive gender diversity. If women bring value to boardrooms as companies and investors alike believe, then ensuring that they are able to contribute equally must become an integral part of the existing discourse. Second, the Article discusses the regulatory implications and suggests a shift towards an enhanced disclosure regime that would require companies to provide investors with both substantive and quantitative measures of gender diversity with respect to the boardroom.

208. See, e.g., Institutional S'holder Servs., Inc., Gender Parity on Boards Around the World, Harv. L. Sch. F. CORP. GovernanCE \& Fin. ReG. (Jan. 5, 2017), https://corpgov law.harvard.edu/2017/01/05/gender-parity-on-boards-around-the-world [https://perma.cc /AY42-44KS] (describing the ability to focus on nomination without culture changes); Kunal Sehgal, Indian Companies in Mad Rush to Find Women Board Members, CNN MonEY (Apr. 6, 2015, 10:24 PM), http://money.cnn.com/2015/04/06/investing/india-corporate-boards -women [https://perma.cc/HS3L-8RB6]. 


\section{A. A Focus on Substantive Diversity}

Prior studies, investor demands, and policy arguments have focused on quantitative measures or a diversity threshold. ${ }^{209}$ That is, existing literature has recommended that companies either meet some gender diversity threshold, disclose their plans to reach some set number of female directors, or explain their failure to do so. ${ }^{210}$ Though an increase in the absolute number of women on boards is clearly important, and does provide more "diversity," the findings in Part II illustrate the need to augment this information with data on the specific roles that women perform on any given board.

Granted, the appeal of the quantitative approach is understandable. Quantitative measurements of diversity can provide a bird's eye view of boardroom diversity. They are easier to analyze and monitor. They are less murky or subject to interpretation. Their strength is in their simplicity and straightforwardness. The focus on increasing the ratio of women on boards also has undeniable benefits. Female directors provide a new or different perspective on board decisions. ${ }^{211}$ These additional viewpoints provide a better opportunity for thoughtful business decisions. ${ }^{212}$ A higher number of female directors could also help improve the general gender diversity in the company. ${ }^{213}$ The more women on the board, the more likely that the company promotes gender diversity from within. ${ }^{214}$

However, a sole focus on quantitative measurements misses the mark in assessing and promoting true corporate board diversity. Corporations required to meet quantitative diversity metrics can focus on achieving that metric without changing the board's culture or the board's nomination procedures. ${ }^{215}$ That is, a nominating committee whose continued directorship is dependent on nominating an additional woman (due to the threat of withhold campaigns by investors) will do just that. However, it does not necessarily follow that the company will enact a policy to include more women in their future searches or afford women, directly and indirectly, with equal power within the boardroom or attempt to increase diversity throughout the corporation.

Substantive measurements add color to the monochrome image that the number and ratio of women provides us. They move away from solely asking companies to meet a specific number of positions to be filled by gender diverse candidates. Instead, it also allows for fluidity among companies to focus on the diversity aspects within the boardroom work it, or its investors, finds important.

209. See EASTMAN ET AL., supra note 100.

210. See, e.g., DHIR, supra note 20; Rosenblum \& Roithmayr, supra note 109.

211. See Hong \& Page, supra note 96.

212. Id.; see also Exclusive Interview: Empowering Board Evaluation and Refreshment, EQUILAR (June 13, 2017), https://www.equilar.com/blogs/273-semler-brossy-board-diversity -interview.html [https://perma.cc/C58G-BYTE] (explaining that "board representation leads to more conversation and questioning that can lead to better answers and outcomes").

213. Eastman et Al., supra note 100, at 9; Vivian Hunt, Dennis Layton \& Sara Prince, Why Diversity Matters, MCKINSEY \& Co. (Jan. 2015), http://www.mckinsey.com/business -functions/organization/our-insights/why-diversity-matters [https://perma.cc/9MK6-LEKN].

214. EASTMAN ET AL., supra note 100, at 9.

215. See supra text accompanying note 208. 
Importantly, the inclusion of substantive measures does not take away from the ability, and need, of boards to increase the number of women or diverse directors on the board. Rather, it incentivizes these companies to increase gender diversity quantitatively while also ensuring that ample attention is given to the substantive gender parity within the boardroom. Because the absolute number of diverse candidates on the board will still likely be dispositive towards any measure of diversity, a company will still be incentivized to increase the number of women on the board. However, it provides well-intentioned companies the opportunity to organically grow their gender diversity. ${ }^{216}$

Indeed, the data highlights the ties between these metrics. For example, women are more likely to stay on the board for longer if the ratio of women on the board is higher. Similarly, the presence of female directors in leadership roles is positively correlated to longer tenure of the rest of the female directors on the same board.

As a result, investors should expect companies to do more than just add an additional female to the board. For example, if the tenure of women is correlated with their likelihood to take on leadership roles, as this Article finds, then investors must scrutinize companies in which women's tenure is low. Similarly, if the presence of a woman in a leadership role can influence the willingness of women to stay longer, then investors must account for that in their valuation of the company's gender diversity. If the fact that women are stretched too thin prevents them from taking on leadership roles, then investors should consider asking companies to limit the committee work that each director can do.

Companies themselves must also take a proactive approach. Companies must examine their corporate culture and make sure that women are not stretched too thin in their committee work, which could keep them from taking more active leadership roles. Companies may also want to consider term limits for leadership roles, allowing more women on the board to get an opportunity to serve in these roles. Companies should also promote structured and clear opportunities for women to move up into leadership roles, including mentorship. ${ }^{217}$

Public attention and regulatory emphasis should also take account of the substantive measures of board diversity. A focus on substantive measures of board diversity in addition to quantitative data on companies' current and historic gender diversity ratios would accomplish the core of gender diversity initiatives by asking a simple, yet underaddressed, question: How do corporate policies and corporate governance truly advance gender diversity?

\section{B. Regulatory Reform}

What regulatory intervention, if any, should be advocated for implementation in the United States? ${ }^{218}$ Different jurisdictions around the world have approached the

216. For example, if a board does not find a female director within the next year or two but attempts to cultivate diversity within the board by affording women stronger voice, it can explain this process to investors, allowing more time to increase the actual number of women.

217. Joann S. Lublin, Boards Try Buddy System to Get Newcomers Up to Speed, WaLl ST. J. (Sept. 18, 2017, 5:10 PM), https://www.wsj.com/articles/boards-try-buddy-system-to-get -newcomers-up-to-speed-1505769025 [https://perma.cc/WU7R-X57K].

218. See DHIR, supra note 20, at 71-94. Similarly, of a panel of five professors, researchers 
issue in diverse ways. ${ }^{219}$ First, some countries have placed hard quotas on board composition, requiring either progressive representation by board size or simply requiring some minimum number of female directors. ${ }^{220}$ Second, some countries have adopted softer laws otherwise known as comply-or-explain provisions. ${ }^{221}$ These laws require boards to either meet a specific quota or state the affirmative reasons for failing to comply with the law. ${ }^{22}$ Third, some countries (including the United States) have placed minimal to no regulations regarding gender diversity. ${ }^{223}$ As expected, the fewer or softer the regulations, the lower the female board participation rate. ${ }^{224}$

Though, generally speaking, tougher regulations lead to better female board participation, other factors, including societal views towards gender, have a significant impact on women's board participation. ${ }^{225}$ Sweden, for example, has no required quota for board participation, yet still has some of the highest parity between the genders on boards. ${ }^{226}$ On the other hand, a country like India has a hard law requiring at least one female on every board. ${ }^{227}$ However, in complying with the regulation, $83.5 \%$ of Indian corporations have only one female on the board. ${ }^{228}$ Further, only $59 \%$ of boards have an independent female director. ${ }^{229}$ Though both show extreme examples of the spectrum, these countries prove the difficulty in addressing board gender parity. Thus, gender diversity activists disagree as to whether a quota enacts the meaningful change sought.

As a practical matter, quotas are an unlikely regulatory avenue in the United States, as they would face legal hurdles ${ }^{230}$ and are unlikely to garner investor or

and administrators at the University of Wisconsin Journal of Law, Gender \& Society Symposium in Spring 2017, each panelist had either a different opinion on the necessity of quotas, as well as the implementation thereof. Symposium, Women in the Boardroom: The Social and Business Arguments that Challenge Executive Board Homogeneity, WIS. J.L. GENDER \& SOC'Y (2017).

219. See, e.g., Institutional S'holder Servs., supra note 208 (describing the different approaches); Darren Rosenblum \& Daria Roithmayr, The Conference BD., The EfFect OF GENDER DiVERSITY ON BOARD DECISION-MAKING (2017).

220. Institutional S'holder Servs., Inc., supra note 208; see also DHIR, supra note 20, at $71-94$.

221. Institutional S'holder Servs., Inc., supra note 208.

222. See, e.g., DHIR, supra note 20, at 240-48 (explaining the comply or explain model in the context of gender diversity disclosure).

223. Institutional S'holder Servs., Inc., supra note 208.

224. Id.

225. Id.

226. Id.

227. Id.

228. See id.; News articles have documented the extreme examples of CEOs and chairmen of boards complying with the law by hiring wives and relatives of board members. Much of these articles suggest that a substantial number of these directorships have only been extended to remain in compliance with the regulations and are not due to a belief of any added value. E.g., Sehgal, supra note 208.

229. Institutional S'holder Servs., Inc., supra note 208.

230. See supra text accompanying note 159; see also Darren Rosenblum, Parity/Disparity: Electoral Gender Inequality on the Tightrope of Liberal Constitutional Traditions, 39 U.C. DAVIS L. REV. 1119, 1172-78 (2006). 
regulatory support. ${ }^{231}$ Scholars point to Regents of the University of California $v$. Bakke, in which the Supreme Court specifically rejected quotas in affirmative action policies, ${ }^{232}$ as a likely legal hurdle to potential gender quota regulation in the United States. ${ }^{233}$ Equally important, many of the changes in countries outside the United States that have implemented quotas arose due to public pressure. ${ }^{234}$ However, even adamant supporters of affirmative action policies in the United States strongly disfavor mandatory quotas as a means for remediation, ${ }^{235}$ further undermining a focus on quotas as a remedy to the lack of gender diversity on the board.

Indeed, the SEC has mostly opted to use disclosure as a mean to address issues related to corporate governance and social cause. ${ }^{236}$ It is not surprising then, that in the context of gender diversity in boardrooms, company disclosure has been the natural first step of many regulatory reform proposals. ${ }^{237}$ Moreover, even if gender quotas were on the regulatory table, it is not clear that they would produce sufficient focus on substantive diversity, as quotas are merely an enhanced version of the existing quantitative focus.

The flaws in the current disclosure regime are therefore the logical starting point of any regulatory reform. Recognizing the incongruity between the intention and implementation of the regulation, the SEC under former Chairman Mary Jo White made boardroom diversity a priority, ${ }^{238}$ and House Representatives have recently urged the incoming SEC Chair to amend the diversity disclosure regime. ${ }^{239}$ This recent momentum could make a reconsideration of the current rules more likely, although the current political landscape may present challenges to such reform.

Yet, the current calls for regulatory reform by investors and legislators are focused on the addition of quantitative disclosure regarding the gender/race of directors. ${ }^{240}$ While an important step in itself, the findings presented in this Article highlight that

231. See DHIR, supra note 20, at 78-82.

232. 438 U.S. 265 (1978).

233. Magnier \& Rosenblum, supra note 159, at 262-63.

234. Rosenblum \& Roithmayr, supra note 109, at 893.

235. Alex M. Johnson, Jr., Defending the Use of Quotas in Affirmative Action: Attacking Racism in the Nineties, 1992 U. ILL. L. REV. 1043, 1067 (1992).

236. See, e.g., Steven M. Davidoff \& Claire A. Hill, Limits of Disclosure, 36 SEattLe U. L. REv. 599, 605 (2013) ("Disclosure is the sine qua non of the federal securities law."); Hazen \& Broome, supra note 169, at 44-45; Yaron Nili, Out of Sight, Out of Mind: The Case for Improving Director Independence Disclosure, 43 J. CORP. L. 35, 38 (2017) (“[I]n recent years, effective disclosure has taken on an increasingly pivotal role in corporate law. The SEC has attempted to increase transparency for investors in many regulated areas and topics.").

237. See, e.g., DHIR, supra note 20 at 94-98; Packel, supra note 85, at 220-21 (stating that "despite criticisms and recognition of its limits, disclosure is still the most relied upon mechanism because regulators can point to the fact that they are 'doing something,' and it 'seems responsive and is relatively politically palatable"').

238. Yin Wilczek, The SEC, Mary Jo White and Board Diversity, BLOOMBERG: CorP. TRANSACTIONS BLOG (July 5, 2016), https://www.bna.com/sec-mary-jo-b57982076532 [https://perma.cc/HAT7-GC3H].

239. Letter from Carolyn B. Maloney \& Donald S. Beyer, Jr., Members of Congress, to Jay Clayton, Chair, SEC (May 30, 2017); see supra note 13 and accompanying text.

240. See, e.g., Friedman et al., supra note 11 (reviewing the suggestion by the New York City Comptroller to revise the disclosure of diversity by companies). 
a review of the current standards must also consider substantive diversity measurements. Therefore, if disclosure of gender diversity of boards is needed, as investors and regulators alike have indicated, then a more complete overhaul of the current diversity disclosure regime is warranted.

The findings in Section III.C also underscore the potential intrinsic value of gender diversity disclosure. These findings suggest that the SEC's disclosure regime, if properly modified to address its current deficiencies, could be an appropriate avenue for addressing diversity issues on boards, including incorporating the concept of substantive diversity.

Consequently, the current calls for a disclosure reform should address two distinct issues. First, the SEC must address the current definition of diversity to prevent companies from strategically diluting it. Second, any added disclosure requirements should include both quantitative and substantive measures of diversity.

\section{The Definition of Diversity}

Current SEC disclosure rules focus on whether and how a company considers diversity. As developed above, the current legal framework fails to ensure even this modest task. As discussed in Section III.C, one of the biggest flaws in diversity disclosures is the ability of boards to self-define diversity. ${ }^{241}$ A company can define diversity broadly so long as that definition is provided to investors. ${ }^{242}$ Unfortunately, this provides companies with the opportunity to include any and all potentially diverse characteristics, therefore diluting the specific interest in gender diversity. For example, companies may include "differences of viewpoint" as a measure of diversity. ${ }^{243}$ If a company defines itself as diverse merely because it has "difference of viewpoints," then how is an investor expected to evaluate that board?

Permitting companies to define diversity allows the company to include all of the aspects of diversity the company values. However, any regulation should still include a specific set of gender diversity measures ${ }^{244}$ for which each company must provide data, in order to promote homogeneity amongst corporate diversity disclosures. By requiring companies to define diversity clearly using a prerequisite list of clear and measurable diversity factors, ${ }^{245}$ investors can consciously vote for or against boards meeting their expectation of diversity.

241. See DHIR, supra note 20, at 230-40 (addressing the issue of the current definition of diversity).

242. See, e.g., United Cont'l Holdings, Inc., Proxy Statement (Form DEF 14A) 25 (Apr. 21, 2017).

243. See, e.g., AmTrust Fin. Servs., Inc., Proxy Statement (Form DEF 14A) 9 (Apr. 11, 2017); Axalta Coating Sys., Ltd., Proxy Statement (Form DEF 14A) 11 (Mar. 15, 2017); Knight Transp., Inc., Proxy Statement (Form DEF 14A) 13 (Mar. 31, 2017); Urban Outfitters, Inc., Proxy Statement (Form DEF 14A) 9 (Apr. 3, 2017).

244. The focus of this Article is on gender diversity. Clearly, a case can be made for including potentially other diversity areas, but this is not the purview of this Article.

245. For similar proposals, see DHIR, supra note 20, at 231-33; Packel, supra note 85, at 235-36. 


\section{Adding a Substantive Gender Diversity Disclosure}

The deficiencies in the current disclosure regime extend beyond the open-ended treatment of diversity or the lack of effective disclosure by companies regarding their approach to gender diversity on the board. Investors are also left in the dark regarding the actual diversity in the boardroom. Recognizing the value in accounting for both quantitative and substantive measures, this Article calls for the adoption of a "Substantive Gender Diversity Disclosure" (SGDD) that would be required of each company. The SGDD would require the company to provide a clear table, similar to other disclosures such as director and executive compensation that summarizes many of the measures highlighted above. The data should include the current ratio of women to men on the board, the specific roles of women on the board compared to men (with a specific breakdown of leadership positions), a comparative breakdown of age and tenure, and any additional specific insight into how its board and its corporate structure promote diversity.

Currently, most diversity statements included in proxy forms are drafted in narrative form and remain vague, simply stating all diversity factors that are potentially relevant into nominating directors. ${ }^{246}$ Diversity disclosures should, in addition to the definition of diversity, clearly state how diverse a company is by using both measurable metrics (quantitative and substantive) and company policies promoting diversity within the boardroom and the company. The SGDD, as a concept, is meant to carry this function.

Indeed, requiring companies to provide substantive disclosures of board diversity, in addition to quantitative data on their current and historic gender diversity ratios, would accomplish the core of gender diversity initiatives: Do we truly achieve gender diversity?

An SEC amendment to its diversity rules that would potentially include the suggested SGDD table carries several benefits. First, it would enable the adoption of a unified SGDD that would allow shareholders to easily compare companies and ensure that all companies are playing on the same playing field. It would also ensure that changes to diversity on boards would occur more rapidly, as current shareholder initiatives are only slowly beginning to gain steam. Finally, SEC led change will also carry with it better enforcement of the new rules. Such institutional enforcement would be lacking through other channels.

While the specific design of the SGDD should be crafted after a detailed regulatory rule-making process, it is important to underscore that the SEC could create a semi-flexible SGDD. By requiring disclosure regarding certain issues, but allowing companies to experiment with policies, measurements, and other disclosed metrics, this flexibility will allow for some organic growth and improvement.

246. See, e.g., Conn. Water Serv., Inc., Proxy Statement (Form DEF 14A) 4-5 (Mar. 30, 2016); Discovery Comm., Inc., Proxy Statement (Form DEF 14A) 10 (Apr. 5, 2017); Essendant Inc., Proxy Statement (Form DEF 14A) 15 (Apr. 13, 2016); Microsoft Corp., Proxy Statement (Form DEF 14A) 13 (Oct. 18, 2016); Navient Corp., Proxy Statement (Form DEF 14A) 29 (Apr. 15, 2016); Six Flags Entm't Corp., Proxy Statement (Form DEF 14A) 8 (Mar. 22, 2016); Skechers U.S.A., Inc., Proxy Statement (Schedule 14A) 17 (Apr. 29, 2016). 


\section{Implementation Through Other Means}

While a change to the current SEC rules would be the most straightforward route for addressing gender diversity disclosure, the current SEC, under the new chair, may be unwilling to take any regulatory steps in the near future. Therefore, companies could hypothetically adopt a SGDD, or similar initiatives, on their own through two other means. First, companies may voluntarily adopt improved disclosures based on the mounting pressure from large investor groups. Second, SGDD could be advocated via the shareholder proposal mechanism. While both are plausible avenues, each suffers from drawbacks that would make them less effective than a regulatory reform route.

\section{Organic Growth}

This Article began by showing the drastic change over the first few months of 2017 with regard to the view of diversity within the boardroom. ${ }^{247}$ State Street and BlackRock have specifically drawn a line in the sand regarding gender diversity: promote more women or risk being voted out. ${ }^{248}$ The impact will likely soon be felt as companies actively look to add women onto the board to avoid an inevitable negative vote. The benefits of this route are clear. Companies will organically move towards more gender diversity with minimum regulatory burdens and without rapid shocks.

However, while this strategy will likely continue to increase the number of women in board directorships, it is not clear that it would lead to better company disclosures. Investors (and very recently Congress) have been advocating for improved quantitative disclosure for several years, with no success. ${ }^{249}$

\section{Shareholder Proposals}

Recent years have brought to the forefront the shareholder proposal ${ }^{250}$ as an effective tool for corporate governance changes. ${ }^{251}$ The increasing importance of proxy advisers coupled with the credible threat of "withhold" campaigns against companies that ignore shareholder concerns have led corporations to pay closer attention to precatory (nonbinding) shareholder proposals that receive significant support by shareholders. The guidelines of ISS and Glass Lewis, the two largest and most influential proxy advisory firms, require companies to act upon shareholder resolutions that pass. ${ }^{252}$ If management ignores successful shareholder proposals,

247. See supra Introduction.

248. Atmeh, supra note 206; Mlyn, supra note 206.

249. See supra note 13 and accompanying text.

250. According to Rule 14(a)(8), an individual shareholder can submit a shareholder proposal if they continuously hold at least $\$ 2000$, in market value, or $1 \%$ of the company's stock for at least one year prior to the shareholder meeting. Shareholder Proposals, 17 C.F.R. $\S 240.14 \mathrm{a}-8$ (b) (2018).

251. See, e.g., Kastiel \& Nili, supra note 65; Paul Rose, Shareholder Proposals in the Market for Corporate Influence, 66 FLA. L. REV. 2179 (2014).

252. See Glass Lewis \& Co., Proxy Paper Guidelines: 2015 Proxy Season 1, 7-8, 28 
proxy advisory firms are likely to recommend against votes on individual directors (or the entire board), and such directors could be subject to potential withhold campaigns. In essence, such practice has transferred the so-called "precatory" shareholder proposals into "quasi-binding" resolutions. This suggests that companies nowadays face more severe sanctions if an unwelcomed shareholder proposal passes. ${ }^{253}$

Indeed, the ability of shareholders to discipline board members through withholding votes from directors' nominees has become a major way for passive shareholders to express their voice within the current regulatory framework and to signal to the board that they are dissatisfied with its actions. In light of this new reality, some companies prefer to negotiate and work with the proposing shareholder to enact some change without having it go to a shareholder vote. ${ }^{254}$ If the shareholder is successful with either method, then the company will likely change its corporate governance to avoid future negative votes for failing to enact the proposal.

In the area of diversity disclosure, shareholders can submit proposals that are individualized to each company or, more than likely, in the form of a standard proposal. Shifting the aim of the shareholder-initiated proposals from the gender ratios or quantitative disclosure to substantive disclosure carries an additional benefit. It is a more modest request from the company and one that falls within the core rights of shareholders. By merely requiring the company to provide meaningful backward-looking information on diversity, the company is not necessarily required to change anything other than providing an additional disclosure. It is likely that requiring the disclosure will produce these changes as companies attempt to appease shareholders through their disclosures. However, these changes do not directly arise from the shareholder proposal but rather are indirect effects of transparency.

Not only will the less stringent requirements of the disclosure offer a better opportunity for adoption, but the support of passive investors will also make these proposals more likely to pass. With CalPERS and CalSTRS highly invested in many passive funds, ${ }^{255}$ their support for gender diversity will flow through to the voters of

(2015), http://www.glasslewis.com/assets/uploads/2013/12/2015_GUIDELINES_United _States.pdf [https://perma.cc/BK8V-PBEK]; InSTITUTIONAL S'HOLDER SERVs., United States Summary Proxy Voting Guidelines: 2015 Benchmark Policy RECOMMENDATIONS 13 (Dec. 22, 2014), http://www.issgovernance.com/file/policy /2015ussummaryvotingguidelines.pdf [https://perma.cc/Y7NM-4E33].

253. See Yonca Ertimur, Fabrizio Ferri \& Stephen R. Stubben, Board of Directors' Responsiveness to Shareholders: Evidence from Shareholder Proposals, 16 J. CORP. FIN. 53 (2010) (providing empirical evidence that managers and directors who ignore majority vote shareholder proposals are more likely to face sanctions in the labor market); Kobi Kastiel, Against All Odds: Hedge Fund Activism in Controlled Companies, 2016 Colum. Bus. L. Rev. 101, 148-49 (2016) (discussing the mechanism behind the increasing disciplinary effect of $14 \mathrm{a}-8$ shareholder proposals).

254. Stephen Joyce, Negotiations Lead to Fall in Proxy Access Proposals, BLoomberg (June 30, 2016), https://www.bna.com/negotiations-lead-fall-n57982076332 [https:// perma.cc/JL6Q-TNPB] (reporting that "an increasing number of companies negotiating settlements with shareholders led to a material decrease in the number of shareholder proposals seeking proxy access in 2016").

255. See State Street Global Advisors Launches Gender Diversity ETF to Help Investors Seek a Return on Gender Diversity, Bus. WIRE (Mar. 7, 2016, 8:58 AM), https://www 
these passive funds. Thus, a shareholder proposal supporting gender diversity is likely to be viewed and voted positively by these funds. In turn, companies will likely be more inclined to adopt shareholder proposals before shareholder vote knowing the likelihood of passive fund support is high.

However, shareholders have yet to focus on the substantive aspect of diversity, opting to focus on the more tangible quantitative issue. Indeed, while shareholders are currently submitting proposals for gender diversity initiatives, ${ }^{256}$ most of these proposals suggest a company establish practices for identifying and adding female board directors. ${ }^{257}$ However, the focus in these proposals is still more in the nomination process rather than the roles directors take within the board. ${ }^{258}$

Moreover, the shareholder proposal route has yet to garner sufficient support. Gender diversity proposals have struggled to attain the requisite votes to put the proposal into action, ${ }^{259}$ partially since some of the largest shareholders of companies routinely withhold votes on social issues, as they prefer to engage directly with the company. ${ }^{260}$ In 2016, only one in nine of such proposals received the votes necessary to pass. ${ }^{261}$ However, these numbers do not account for submitted proposals that were settled prior to vote. ${ }^{262}$ It is possible that some of these proposals were negotiated on

.businesswire.com/news/home/20160307005890/en/State-Street-Global-Advisors-Launches -Gender-Diversity [https://perma.cc/7ZAM-RC2Q] ("SSGA was inspired to develop the Index by [CalSTRS] efforts to move the needle on gender diversity in corporate America, especially for women in leadership positions.").

256. See Green \& Chasan, supra note 62; Katz \& McIntosh, supra note 66.

257. For example, Discovery Communications received the following proposal in 2016: Shareholders request that the Board of Directors prepare a report by September 2016, at reasonable expense and omitting proprietary information, on steps Discovery Communications is taking to foster greater diversity on the Board over time including but not limited to the following: 1. The inclusion of women and minority candidates in every pool from which Board nominees are chosen and our company's plan to advance Board diversity; 2. An assessment of challenges experienced and progress achieved.

Discovery Comm., Inc., Proxy Statement (Form DEF 14A) 76 (Mar. 30, 2016). In 2017, Discovery then received the following proposal:

Shareholders request that the Board of Directors of Discovery Communications adopt a policy for improving board diversity (the "Policy") requiring that the initial list of candidates from which new management-supported director nominees are chosen (the "Initial List") by the Nominating and Corporate Governance Committee should include (but need not be limited to) qualified woman and minority candidates. The Policy should provide that any third-party consultant asked to furnish an Initial List will be asked to include such candidates.

Discovery Comm., Inc., Proxy Statement (Form DEF 14A) 89 (Apr. 5, 2017).

258. See, e.g., Discovery Comm., Inc., Proxy Statement (Form DEF 14A) 6 (Apr. 5, 2017).

259. See Green \& Chasan, supra note 62; Katz \& McIntosh, supra note 66.

260. See, e.g., Policies and Guidelines: Environmental and Social Matters, VAnguard, https://about.vanguard.com/investment-stewardship/policies-and-guidelines [https://perma.cc /TJF2-FHSQ] (noting the differences amongst investors and the difficulty to support the views amongst these investors).

261. See Green \& Chasan, supra note 62; Katz \& McIntosh, supra note 66.

262. Joyce, supra note 254. 
or completely enacted by the company before the shareholder vote and therefore never had an opportunity to be voted on.

\section{Potential Objections}

This Section considers and responds to several possible objections to the proposed disclosure reforms and the focus on substantive disclosure.

\section{1. "Substantive Murkiness"}

On its face, substantive diversity disclosures will make it more difficult for investors to determine whether a company has sufficiently increased its diversity. Quantitative measures are simple. A company reaches a predefined percentage threshold or some absolute number and is consequently determined to be sufficiently diverse. Therefore, the murkiness that a focus on a substantive disclosure may create might detract from such efforts.

However, this argument misses the mark on several fronts. First, as discussed above, the design of the substantive disclosure can establish easy, quantifiable parameters such as tenure, lead roles, committee chairs, and more. These quantifiable measures would allow for more clarity into the substantive parity in the boardroom, while also providing clear benchmarks of comparison. Second, the substantive disclosures are not mutually exclusive with the general push for more diversity in the board nomination process. To the contrary, the suggested SGDD would include the quantitative data. The addition of the substantive data may incentivize companies to take additional substantial steps to prove they have met the requisite diversity.

\section{Overinclusiveness}

Some critics may argue that current disclosure requirements are sufficient and that any additional disclosures would lead to overinclusiveness and to overloading investors with information. Further, to counter the possible concerns of investors, companies may provide information that is clearly immaterial, placing unnecessary costs on the company and for investors who would need to comb through this information.

However, this argument is also lacking in several aspects. First, forcing the board to be overinclusive and shining light on substantive diversity disclosure allows for a better assessment of the board's substantive diversity. Second, shareholders are more than capable of properly digesting this information with the help of sophisticated investors and proxy advisers. Third, the general trend in current corporate governance is for more information rather than less. ${ }^{263}$ There is no reason to deviate from this approach when it comes to diversity.

263. Mary Jo White, Statement at an Open Meeting on Regulation S-K Concept Release, SEC (Apr. 13, 2016), https://www.sec.gov/news/statement/white-statement-1-041316.html [https://perma.cc/2DHR-GG98] (highlighting the role and importance of improved and more detailed disclosures to shareholders). 


\section{Questionable Diversity Practices Will Persist}

A third potential objection is that changing disclosure requirements will not cure the problem of substantive parity in the boardroom. Companies may react by better camouflaging their board practices, and some investors will look differently at different substantive markers, placing different "diversity scores" for each company.

However, the proposed changes are designed to increase investor transparency rather than force substantive parity on companies. A focus on substantive factors in addition to the quantitative ratios would better educate investors of their company's board's true diversity. In turn, better investor awareness to both quantitative and substantive aspects of diversity might allow each company to strike its own optimal diversity balance, both in terms of quantity and roles that women take on the board.

\section{Private Ordering}

If substantive disclosure is important, and value enhancing, then supporters of the market view could ask why we do not see companies adopt it without regulatory intervention. There are several reasons, however, to be skeptical of reliance on the market alone to drive these changes. First, companies lack the incentive to provide this information to shareholders, as it may reveal the true diversity gap on the board, even where the number of women directors is relatively high. Second, while shareholders could value the substantive aspect of diversity, focusing on the quantitative aspect has seemed to be the focus of their initiatives. As explained above, some of it is a strategic focus on more observable issues, but this Article contends that some of it is also due to the lack of current attention to the roles women take in the boardroom after being elected. Finally, market movement is already happening, but it is inherently slow. The Article highlighted two "private ordering" avenues through which we may see a move towards substantive diversity disclosure. However, the Article also highlighted the benefits that a centralized regulatory intervention may provide, one that the market is unlikely to produce.

\section{CONCLUSION}

The current SEC regulatory framework fails to adequately disclose to investors the substantive representation of female directors on the board or even provide the ratio of women on the board. While previous studies have introduced evidence that social and economic reasons exist for increasing gender diversity, many companies have lagged behind in introducing policies aimed at searching for and cultivating gender diversity. The key argument developed in this Article is that while a focus on the number of women on boards is important and a central first step in the quest for true gender parity, it cannot be the only lens through which gender diversity is examined. Rather, investors and boards should also focus on a substantive disclosure of female boardroom participation.

Substantive disclosures complement the quantitative data in that they provide a more nuanced account of the substantive diversity in the boardroom, while also providing companies with the ability and flexibility to draft policies and propose corporate changes applicable to their situation. Rather than encouraging companies to meet some specific gender diversity metric, companies will be incentivized to 
delve deeper into gender diversity and disclose their method for doing so. This provides investors with the possibility of meaningful change they seek and improves transparency into the corporate governance procedures of leading companies. Coupled with prior studies indicating positive correlations between gender diversity and company performance, increased disclosure could provide positive benefits to corporate America and society at large.

Equally important, recognizing the import of substantive gender diversity necessitates further research into the intraboard dynamics. This Article has used available data to examine several disparities between the genders. However, our understanding of substantive diversity would greatly benefit from additional data points on the respective roles that the genders take in the boardroom.

The recent focus on board gender equity has started to move the needle, but gender equity is still sorely missing from most public companies in the United States. The substantive and leadership gaps between the genders on public companies' boards must shift gender diversity advocates away from a micro-focus on numbers. The past year proved that change is possible. Now, investors and regulators must turn their attention beyond the numbers to the systematic disparities between women and men on boards. If women are not moving into positions of power on boards or are otherwise treated differently on boards, we need to know why, and we need to understand the cost. 